\title{
COMENTARIO A LA SENTENCIA DE LA CORTE INTERAMERICANA DE DERECHOS HUMANOS, CASO «ATALA RIFFO Y NIÑAS VS. CHILE», DE 24 DE FEBRERO DE 2012
}

FRANCISCO ZÚÑIGA URBINA 



\title{
COMENTARIO A LA SENTENCIA DE LA CORTE INTERAMERICANA DE DERECHOS HUMANOS, CASO «ATALA RIFFO Y NIÑAS VS. CHILE», DE 24 DE FEBRERO DE 2012
}

\author{
FRANCISCO ZÚÑIGA URBINA \\ Catedrático de Derecho Constitucional \\ Universidad de Chile
}

Esta sentencia se enmarca dentro de un proceso llevado ante la Corte Interamericana de Derecho Humanos (CIDH o la Corte), por haberse afectado los derechos de la Sra. Karen Atala Riffo, abogada y jueza, quien fue privada de la tuición de sus tres hijas en un contencioso de familia entablado por su ex cónyuge Sr. Jaime López Allendes, abogado, por sentencia dictada por la sala respectiva de la Corte Suprema. La sentencia de la Corte Suprema, conociendo de un recurso de queja, en donde se estableció que los jueces de primera y segunda instancia, que habían concedido la tuición a la Sra. Atala Riffo, habían incurrido en falta o abuso, ya que no habían considerado el interés superior de las niñas al momento de resolver el caso, interés que se vería afectado por el entorno del hogar de la madre de las niñas, quien es homosexual (lesbiana) y convivía con su pareja Sra. Emma De Ramón, historiadora, en la misma casa con sus hijas; sentencia que contiene una disidencia en orden a que la orientación sexual de la madre por sí misma — sin que se prueben en concreto los daños o riesgos para las menores- no es un argumento válido para decidir sobre la tuición o custodia de los padres.

En el mes de Enero de 2003, el padre de las niñas López Allendes interpuso demanda de tuición, al considerar que el desarrollo de las menores se estaba viendo afectado por la convivencia con su madre. El Juzgado de Menores de Villarrica concedió la tuición provisional al padre de las niñas. El día 29 de Octubre de 
2003, este mismo juzgado rechazó la demanda de tuición del padre, estableciendo que la opción sexual de la madre no afectaba el desarrollo de las niñas, de este modo se ordena la entrega de las niñas a la madre con fecha 18 de Diciembre de 2003 .

Sin embargo, el 11 de Noviembre de 2003, se entabló recurso, ante la Corte de Apelaciones de Temuco, que dictó orden de no innovar, manteniendo la tuición provisional en el padre. Sin embargo, en la sentencia definitiva de la causa de familia, dictada el día 30 de Marzo de 2004, la Corte de Apelaciones confirma íntegramente la sentencia de primera instancia, rechazando la demanda de tuición. Ante esta decisión judicial, el padre interpone recurso de queja en contra de la sentencia de la Corte de Apelaciones, el día 5 de Abril de 2004. Este recurso es fallado con fecha 31 de Mayo de 2004, revocándose la sentencia de la Corte de Apelaciones y concediéndose la demanda del padre.

A juicio de la Corte Suprema, la que falla revocando sentencia confirmatoria de la Corte de Apelaciones de Temuco en sede de recurso de queja, en la especie se crea una situación que afecta el bienestar de las niñas, las que podrían sufrir discriminación y confusión en los roles sexuales, por lo que se concluye que se ha antepuesto el interés de la madre al de las hijas.

Ante esta situación, la jueza Karen Atala Riffo concurre a la Comisión Interamericana de Derechos Humanos, la que con fecha 17 de Septiembre de 2010, presenta, de conformidad a los artículo 51 y 61 de la Convención Americana de Derechos Humanos (la Convención), demanda en contra del Estado de Chile, por haberse incurrido en un trato discriminatorio en contra de la afectada y una interferencia en su vida privada y familiar, producto de su orientación sexual, durante el proceso de cuidado y custodia de sus hijas.

\section{CONSIDERACIONES DE LA CORTE}

En primer lugar, la Corte define el ámbito de su competencia, en relación con los conflictos jurídicos específicos ventilados en sede judicial chilena, señalando:

«64.- De los alegatos presentados por el Estado, así como de la prueba que obra en el expediente, la Corte considera que en el juicio de tuición se debatieron, inter alia, los siguientes aspectos: i) la orientación sexual de la señora Atala; ii) la personalidad de la señora Atala; iii) los presuntos daños que se habrían ocasionado a las niñas, y iv) la alegada prevalencia que daría la señora Atala a sus intereses personales. Por su parte, respecto del padre de las niñas se expusieron, en el marco del proceso de tuición, argumentos a favor y en contra sobre si él podría brindar un mejor bienestar a éstas. El Estado consideró que la Corte Interamericana debe analizar la totalidad de prueba ventilada en el juicio de tuición y no solamente las sentencias emitidas por los tribunales internos. 
65.- Al respecto, el Tribunal reitera que la jurisdicción internacional tiene carácter subsidiario ${ }^{1}$, coadyuvante y complementario, en razón de lo cual no desempeña funciones de tribunal de «cuarta instancia». La Corte no es un tribunal de alzada o de apelación para dirimir los desacuerdos entre las partes sobre algunos alcances de la valoración de prueba o de la aplicación del derecho interno en aspectos que no estén directamente relacionados con el cumplimiento de obligaciones internacionales de derechos humanos. Es por ello que ha sostenido que, en principio, "corresponde a los tribunales del Estado el examen de los hechos y las pruebas presentadas en las causas particulares».

66. - De acuerdo con lo anterior, no corresponde a este Tribunal determinar si la madre o el padre de las tres niñas ofrecían un mejor hogar para las mismas ni valorar prueba con ese fin específico, pues ello se encuentra fuera del objeto del presente caso, cuyo propósito es definir si las autoridades judiciales han afectado o no obligaciones estipuladas en la Convención. Asimismo, y en razón del carácter subsidiario del Sistema Interamericano, la Corte no es competente para resolver respecto a la custodia de las tres niñas M., V. y R., por cuanto esto es materia del derecho interno chileno. De manera que la tuición actual de las menores de edad no es materia del presente caso.»

\section{EL DERECHO A LA IGUALDAD Y LA PROHIBICIÓN DE DISCRIMINACIÓN}

En cuanto al examen relativo a la infracción al derecho de igualdad y la prohibición de discriminación, la CIDH inicia con la exposición de las partes en el proceso, señalando:

«72. - Respecto a la presunta violación de los artículos 24 y 1.1 de la Convención Americana, la Comisión alegó que "existe un amplio reconocimiento en los Estados americanos en el sentido de que la discriminación con base en la orientación sexual se encuentra probibida». Argumentó que "la orientación sexual (...) fue el sustento de la decisión de la Corte Suprema de Justicia» debido a que presuntamente se determinó que la señora Atala "no debia conservar la custodia de sus hijas.(por cuanto) convivía con una persona de su mismo sexo». Añadió que se "efectuó una distinción en perjuicio de (la señora) Atala en la aplicación de la ley relevante para la determinación de asuntos de familia, con base en una expresión de su orientación sexual, como lo es la decisión de conformar una pareja y establecer una vida con ella». Agregó que la «decisión de tuición provisional (...) constituyó también

${ }^{1}$ Cfr. Caso Acevedo Jaramillo y otros Vs. Perú. Interpretación de la Sentencia de Excepciones Preliminares, Fondo, Reparaciones y Costas. Sentencia de 24 de noviembre de 2006. Serie C No. 157, párr. 66 y Caso Cabrera García y Montiel Flores Vs. México. Excepción Preliminar, Fondo, Reparaciones y Costas. Sentencia de 26 de noviembre de 2010. Serie C No. 220, párr. 16. 
una distinción efectuada con base en la orientación sexual de la señora Atala». Por otra parte, manifestó que "en el derecho constitucional comparado se ha acudido a la figura de "categoría sospechosa» y, consecuentemente, se ha aplicado un escrutinio estricto a casos relacionados con la orientación sexual».

73. - Los representantes señalaron que los Estados «suscribieron la Convención Americana con una cláusula abierta de no discriminación, por tanto no pueden abora alegar que su nivel de desarrollo politico social no les permite entender que se incluye la orientación sexual dentro de las razones probibidas para discriminar». Alegaron que "(l)a decisión del recurso de queja resulta (...) ser un juicio de escrutinio a la (señora) Atala y a su vida privada, sin considerar sus habilidades maternales, que eran el tema a considerar». Indicaron que dicho "juicio de escrutinio (no se realizó) a la vida del (señor) López, del que nada se sabe, cuestiona o investiga, o de sus habilidades parentales». Por tanto, consideraron que "(e) se sólo becho constituye un tratamiento diferenciado no contemplado en el derecho chileno, y claramente probibido por el derecho internacional». Además, alegaron que "(l) a Corte Suprema de Chile (...) cretót una categoría de personas que por su sola naturaleza, sin importar su comportamiento, no serían bábiles para cuidar a sus propios hijos, equiparándolos con situaciones de maltrato y descuido».

74.- El Estado argumentó que «el (S)istema (Interamericano de Derechos Humanos) requiere de la credibilidad y confianza de los Estados miembros. Una relación de confianza recíproca puede ser afectada si la Corte toma un rol demasiado regulador, sin otorgar consideración al sentir mayoritario de los Estados». El Estado alegó que "al suscribir la (Convención Americana), los Estados miembros consintieron en obligarse por sus disposiciones. Si bien la interpretación jurídica puede ser flexible y el lenguaje de los derechos bumanos reconoce su desarrollo progresivo, los Estados prestaron su consentimiento a una idea de derechos bumanos que tenía en mente ciertos tipos de violación, y no otras que en su momento no existian. De ser necesario ampliar el alcance del tratado, en materias en que no existe un consenso mínimo, la misma (Convención Americana) establece un procedimiento para la incorporación de protocolos que protejan otros derechos».

Luego, la sentencia define el contenido de derecho de igualdad en la Convención, y las obligaciones de los Estados de cara a esta regulación; así como los alcances conceptuales en instrumentos internacionales de la garantía de interdicción de la discriminación (arbitraria):

«79. - Sobre el principio de igualdad ante la ley y la no discriminación, la Corte ba senalado ${ }^{2}$ que la noción de igualdad se desprende directamente de la unidad de naturaleza del género bumano y es inseparable de la dignidad esencial de la persona, frente a la cual es incompatible toda situación que, por considerar superior a un determinado grupo, conduzca a tra-

\footnotetext{
${ }^{2}$ Cfr. Opinión Consultiva OC-4/84, supra nota 83, párr. 55.
} 
tarlo con privilegio; o que, a la inversa, por considerarlo inferior, lo trate con hostilidad o de cualquier forma lo discrimine del goce de derechos que sí se reconocen a quienes no se consideran incursos en tal situación. La jurisprudencia de la Corte también ha indicado que en la actual etapa de la evolución del derecho internacional, el principio fundamental de igualdad y no discriminación ha ingresado en el dominio del jus cogens. Sobre él descansa el andamiaje jurídico del orden público nacional e internacional y permean todo el ordenamiento jurídico ${ }^{3}$.

80. - Además, el Tribunal ha establecido que los Estados deben abstenerse de realizar acciones que de cualquier manera vayan dirigidas, directa o indirectamente, a crear situaciones de discriminación de jure o de facto 4 . Los Estados están obligados a adoptar medidas positivas para revertir o cambiar situaciones discriminatorias existentes en sus sociedades, en perjuicio de determinado grupo de personas. Esto implica el deber especial de protección que el Estado debe ejercer con respecto a actuaciones y prácticas de terceros que, bajo su tolerancia o aquiescencia, creen, mantengan ofavorezcan las situaciones discriminatorias.

81.- La Convención Americana, al igual que el Pacto Internacional de Derechos Civiles y Politicos, no contiene una definición explícita del concepto de «discriminación». Tomando como base las definiciones de discriminación establecidas en el Artículo 1.1 de la Convención Internacional sobre la Eliminación de todas las Formas de Discriminación Racial ${ }^{6}$ y el Artículo 1.1 de la Convención sobre la Eliminación de Todas las Formas de Discriminación contra la Mujer ${ }^{7}$ el Comité de Derechos Humanos del Pacto Internacional de

${ }^{3}$ Cfr. Condición Jurídica y Derechos de los Migrantes Indocumentados. Opinión Consultiva OC-18/03 del 17 de septiembre de 2003. Serie A No. 18, párr. 101 y Caso Comunidad Indígena Xákmok Kásek, supra nota 83, párr. 269.

${ }^{4}$ Cfr. Opinión Consultiva OC-18/03, supra nota 85, párr. 103 y Caso Comunidad Indígena Xákmok Kásek, supra nota 83, párr. 271.

${ }^{5}$ Cfr. Opinión Consultiva OC-18/03, supra nota 85, párr. 104; Caso Comunidad Indígena Xákmok Kásek, supra nota 83, párr. 271, y Naciones Unidas, Comité de Derechos Humanos, Observación General No. 18, No discriminación, 10 de noviembre de 1989, CCPR/C/37, párr. 6.

${ }^{6}$ El Artículo 1.1 de la Convención Internacional sobre la Eliminación de todas las Formas de Discriminación Racial señala: «En la presente Convención la expresión «discriminación racial» denotará toda distinción, exclusión, restricción o preferencia basada en motivos de raza, color, linaje u origen nacional o étnico que tenga por objeto o por resultado anular o menoscabar el reconocimiento, goce o ejercicio, en condiciones de igualdad, de los derechos humanos y libertades fundamentales en las esferas política, económica, social, cultural o en cualquier otra esfera de la vida pública».

${ }^{7}$ El Artículo 1.1 de la Convención Internacional sobre la Eliminación de todas las Formas de Discriminación contra la Mujer señala: «A los efectos de la presente Convención, la expresión "discriminación contra la mujer" denotará toda distinción, exclusión o restricción basada en el sexo que tenga por objeto o resultado menoscabar o anular el reconocimiento, goce o ejercicio por la mujer, independientemente de su estado civil, sobre la base de la igualdad del hombre y la mujer, de los derechos humanos y las libertades fundamentales en las esferas política, económica, social, cultural y civil o en cualquier otra esfera». 
Derechos Civiles y Politicos (en adelante «Comité de Derechos Humanos») ha definido la discriminación como:

toda distinción, exclusión, restricción o preferencia que se basen en determinados motivos, como la raza, el color, el sexo, el idioma, la religión, la opinión política o de otra indole, el origen nacional o social, la propiedad, el nacimiento o cualquier otra condición social, y que tengan por objeto o por resultado anular o menoscabar el reconocimiento, goce o ejercicio, en condiciones de igualdad, de los derechos humanos y libertades fundamentales de todas las personas $^{8}$.

82.- La Corte reitera que, mientras la obligación general del artículo 1.1 se refiere al deber del Estado de respetar y garantizar «sin discriminación» los derechos contenidos en la Convención Americana, el artículo 24 protege el derecho a «igual protección de la ley» ${ }^{9}$. Es decir, el artículo 24 de la Convención Americana probíbe la discriminación de derecho o de becho, no sólo en cuanto a los derechos consagrados en dicho tratado, sino en lo que respecta a todas las leyes que apruebe el Estado y a su aplicación. En otras palabras, si un Estado discrimina en el respeto o garantía de un derecho convencional, incumpliría la obligación establecida en el articulo 1.1 y el derecho sustantivo en cuestión. Si, por el contrario, la discriminación se refiere a una protección desigual de la ley interna o su aplicación, el hecho debe analizarse a la luz del artículo 24 de la Convención Americana ${ }^{10}$.»

\subsection{Orientación Sexual}

Luego, la Corte Interamericana de Derechos Humanos analiza específicamente la orientación sexual, como una de las categorías protegidas por el Art. 1.1 de la Convención, que se enmarca dentro de la prohibición de la discriminación por «cualquier otra condición social»; siendo un patrón hermenéutico basal de los derechos humanos el progresivo-evolutivo. De esta forma, se señala en la sentencia:

«83.- La Corte ha establecido, al igual que el Tribunal Europeo de Derechos Humanos, que los tratados de derechos humanos son instrumentos vivos, cuya interpretación tiene

\footnotetext{
${ }^{8}$ Naciones Unidas, Comité de Derechos Humanos, Observación General No. 18, No discriminación, supra nota 87, párr. 6.

${ }^{9}$ Cfr. Opinión Consultiva OC-4/84, supra nota 83, párrs. 53 y 54 y Caso Barbani Duarte y Otros Vs. Uruguay. Fondo, Reparaciones y Costas. Sentencia de 13 de octubre de 2011. Serie C No. 234, párr. 174.

${ }^{10}$ Mutatis mutandi, Caso Apitz Barbera y otros ( CCorte Primera de los Contencioso Administrativo») Vs. Venezuela. Excepción preliminar, Fondo, Reparaciones y Costas. Sentencia de 5 de agosto de 2008. Serie C No. 182, párr. 209 y Caso Barbani Duarte y otros, supra nota 91, párr. 174.
} 
que acompañar la evolución de los tiempos y las condiciones de vida actuales ${ }^{11}$. Tal interpretación evolutiva es consecuente con las reglas generales de interpretación consagradas en el artículo 29 de la Convención Americana, así como las establecidas por la Convención de Viena sobre el Derecho de los Tratados ${ }^{12}$.

84.- En este sentido, al interpretar la expresión «cualquier otra condición social» del artículo 1.1. de la Convención, debe siempre elegirse la alternativa más favorable para la tutela de los derechos protegidos por dicho tratado, según el principio de la norma más favorable al ser bumano ${ }^{13}$.

85.- Los criterios específicos en virtud de los cuales está probibido discriminar, según el artículo 1.1 de la Convención Americana, no son un listado taxativo o limitativo sino meramente enunciativo. Por el contrario, la redacción de dicho artículo deja abiertos los criterios con la inclusión del término "otra condición social» para incorporar así a otras categorías que no bubiesen sido explícitamente indicadas. La expresión «cualquier otra condición social» del artículo 1.1. de la Convención debe ser interpretada por la Corte, en consecuencia, en la perspectiva de la opción más favorable a la persona y de la evolución de los derechos fundamentales en el derecho internacional contemporáneo ${ }^{14}$.

86. - Al respecto, en el Sistema Interamericano, la Asamblea General de la Organización de Estados Americanos (en adelante «OEA») ba aprobado desde 2008 en sus sesiones anuales cuatro resoluciones sucesivas respecto a la protección de las personas contra tratos discriminatorios basados en su orientación sexual e identidad de género, mediante las cuales se ha exigido la adopción de medidas concretas para una protección eficaz contra actos discriminatorios.

En este mismo sentido se cita la jurisprudencia del Tribunal Europeo de Derechos Humanos y del Sistema Universal de Protección a los Derechos Humanos:

«87.- Respecto a la inclusión de la orientación sexual como categoría de discriminación probibida, el Tribunal Europeo de Derechos Humanos ha señalado que la orientación sexual

${ }^{11}$ Cfr. El Derecho a la Información sobre la Asistencia Consular en el Marco de las Garantías del Debido Proceso Legal. Opinión Consultiva OC-16/99 de 1 de octubre de 1999. Serie A No. 16, párr. 114 y Caso de la Masacre de Mapiripán Vs. Colombia. Fondo, Reparaciones y Costas. Sentencia de 15 de septiembre de 2005. Serie C No. 134, párr. 106. En el Tribunal Europeo ver T.E.D.H., Caso Tyrer v. Reino Unido (No. 5856/72), Sentencia de 25 de abril de 1978, párr. 31.

${ }^{12}$ Cfr. Opinión Consultiva OC-16/99, supra nota 93, párr. 114 y Caso de la Masacre de Mapiripán Vs. Colombia, supra nota 93, párr. 106.

${ }^{13}$ Cfr. La Colegiación Obligatoria de Periodistas (Arts. 13 y 29 Convención Americana sobre Derechos Humanos). Opinión Consultiva OC-5/85 del 13 de noviembre de 1985. Serie A No. 5, párr. 52, y Caso de la Masacre de Mapiripán, supra nota 93, párr. 106.

${ }^{14}$ Cfr. Opinión Consultiva OC-16/99, supra nota 93, pára. 115. 
es «otra condición» mencionada en el artículo 14 del Convenio Europeo para la Protección de los Derechos Humanos y de las Libertades Fundamentales (en adelante "Convenio Europeo»), el cual probibe tratos discriminatorios ${ }^{15}$. En particular, en el Caso Salgueiro da Silva Mouta Vs. Portugal, el Tribunal Europeo concluyó que la orientación sexual es un concepto que se encuentra cubierto por el artículo 14 del Convenio Europeo. Además, reiteró que el listado de categorías que se realiza en dicho artículo es ilustrativo y no exhaustivo. Asimismo, en el Caso Clift Vs. Reino Unido, el Tribunal Europeo reiteró que la orientación sexual, como una de las categorías que puede ser incluida bajo "otra condición», es otro ejemplo específico de los que se encuentran en dicho listado, que son consideradas como características personales en el sentido que son innatas o inherentes a la persona.

88. - En el marco del Sistema Universal de Protección de Derechos Humanos, el Comité de Derechos Humanos y el Comité de Derechos Económicos, Sociales y Culturales han calificado la orientación sexual como una de las categorias de discriminación probibida consideradas en el artículo 2.1 del Pacto Internacional de Derechos Civiles y Políticos y el artículo 2.2 del Pacto Internacional de Derechos Económicos, Sociales y Culturales. Al respecto, el Comité de Derechos Humanos indicó en el caso Toonen Vs. Australia que la referencia a la categoría "sexo» incluiría la orientación sexual de las personas. Igualmente, el Comité de Derechos Humanos ha expresado su preocupación frente a diversas situaciones discriminatorias relacionadas con la orientación sexual de las personas, lo cual ha sido expresado reiteradamente en sus observaciones finales a los informes presentados por los Estados.

89. - Por su parte, el Comité de Derechos Económicos, Sociales y Culturales determinó que la orientación sexual puede ser enmarcada bajo "otra condición social». Asimismo, el Comité de los Derechos del Niño, el Comité contra la Tortura y el Comité para la Eliminación de la Discriminación contra la Mujer han realizado referencias en el marco de sus observaciones generales y recomendaciones, respecto a la inclusión de la orientación sexual como una de las categorías probibidas de discriminación.

90.- El 22 de diciembre de 2008 la Asamblea General de las Naciones Unidas adoptó la "Declaración sobre derechos humanos, orientación sexual e identidad de género», reafirmando el "principio de no discriminación, que exige que los derechos humanos se apliquen por igual a todos los seres humanos, independientemente de su orientación sexual o

${ }^{15}$ Cfr. T.E.D.H., Caso Salgueiro da Silva Mouta Vs. Portugal (No. 33290/96), Sentencia de 21 de diciembre de 1999. Final, 21 de marzo de 2000, párr. 28; Caso L. y V. Vs. Austria (No. 39392/98 y 39829/98), Sentencia de 9 de enero de 2003. Final, 9 de abril de 2003, párr. 45; Caso S. L. Vs. Austria (No. 45330/99), Sentencia de 9 de enero de 2003. Final, 9 de abril de 2003, párr. 37, y Caso E.B. Vs. Francia (No. 43546/02), Sentencia de 22 de enero de 2008, párr. 50. 
identidad de género» ${ }^{16}$. Asimismo, el 22 de marzo de 2011 fue presentada, ante el Consejo de Derechos Humanos de Naciones Unidas, la «Declaración conjunta para poner alto a los actos de violencia, y a las violaciones de derechos humanos dirigidas contra las personas por su orientación sexual e identidad de género». El 15 de junio de 2011 este mismo Consejo aprobó una resolución sobre «derechos humanos, orientación sexual e identidad de género» en la que se expresó la "grave preocupación por los actos de violencia y discriminación, en todas las regiones del mundo, (cometidos) contra personas por su orientación sexual e identidad de género». La probibición de discriminación por orientación sexual ha sido resaltada también en numerosos informes de los relatores especiales de Naciones Unidas.»

Por lo tanto, de acuerdo a todo lo que se ha expuesto, la CIDH, determina que la condición sexual (orientación sexual e identidad de género) es una de las categorías o estándares de discriminación prohibida por el derecho internacional convencional en general y por la Convención Americana de Derechos Humanos en particular.

«91.- Teniendo en cuenta las obligaciones generales de respeto y garantía establecidas en el artículo 1.1 de la Convención Americana, los criterios de interpretación fijados en el artículo 29 de dicha Convención, lo estipulado en la Convención de Viena sobre el Derecho de los Tratados, las Resoluciones de la Asamblea General de la OEA, los estándares establecidos por el Tribunal Europeo y los organismos de Naciones Unidas (supra párrs. 83 a 90), la Corte Interamericana deja establecido que la orientación sexual y la identidad de género de las personas son categorías protegidas por la Convención. Por ello está proscrita por la Convención cualquier norma, acto o práctica discriminatoria basada en la orientación sexual de la persona. En consecuencia, ninguna norma, decisión o práctica de derecho interno, sea por parte de autoridades estatales o por particulares, pueden disminuir o restringir, de modo alguno, los derechos de una persona a partir de su orientación sexual.»

\subsection{Diferencia de trato por la orientación sexual}

Seguidamente, la CIDH, examina la distinción en el trato, basada en la orientación sexual, y cuando ella genera una infracción al derecho a la igualdad, fijando, primeramente, un criterio general para dicha determinación:

«94. - El Tribunal resalta que para comprobar que una diferenciación de trato ba sido utilizada en una decisión particular, no es necesario que la totalidad de dicha decisión esté basada "fundamental y únicamente» en la orientación sexual de la persona, pues basta con constatar que de manera explícita o implícita se tuvo en cuenta hasta cierto grado la orientación sexual de la persona para adoptar una determinada decisión.»

${ }^{16}$ Naciones Unidas, Declaración sobre derechos humanos, orientación sexual e identidad de género, Asamblea General de Naciones Unidas, A/63/635, 22 de diciembre de 2008, párr. 3. 


\subsubsection{Relación con el interés superior del niño}

La CIDH, para determinar si es que las diferencias de trato a la Sra. Atala Riffo constituyen una discriminación analiza la justificación que se otorgó por parte de los tribunales chilenos, a saber, el interés superior del niño.

Se señala que, si bien es correcto que el interés superior del niño es un fin legítimo, no puede este basarse en prejuicios o estereotipos, sino que en hechos y circunstancias comprobables o comprobadas:

«107.- La Corte Interamericana constata que, entre sus consideraciones, la Corte Suprema de Justicia de Chile indicó que «en todas las medidas que le conciernan (a los niños y niñas), es primordial atender al interés superior del niño sobre otras consideraciones $y$ derechos relativos a sus progenitores y que puedan hacer necesario separarlo(s) de sus padres» ${ }^{17}$. Por su parte, el Juzgado de Menores de Villarrica, en la decisión de tuición provisoria, manifestó que "es tarea del sentenciador asegurar (...) el interés superior del niño, lo que importa realizar un análisis preventivo o anticipado conducente al fin último que ha de tenerse en cualquier resolución judicial que afecte a un menor (de edad) y que no es otro que procurar su máximo bienestar» ${ }^{18}$.

108. - El objetivo general de proteger el principio del interés superior del niño es, en sí mismo, un fin legítimo y es, además, imperioso. En relación al interés superior del niño, la Corte reitera que este principio regulador de la normativa de los derechos de las niñas y los niños se funda en la dignidad misma del ser humano, en las características propias de los niños y las niñas, y en la necesidad de propiciar el desarrollo de éstos, con pleno aprovechamiento de sus potencialidades ${ }^{19}$. En el mismo sentido, conviene observar que para asegurar, en la mayor medida posible, la prevalencia del interés superior del niño, el preámbulo de la Convención sobre los Derechos del Niño establece que éste requiere «cuidados especiales», y el artículo 19 de la Convención Americana señala que debe recibir «medidas especiales de protección».

109. - Igualmente, la Corte constata que la determinación del interés superior del niño, en casos de cuidado y custodia de menores de edad se debe hacer a partir de la evaluación de los comportamientos parentales específicos y su impacto negativo en el bienestar y desarrollo del niño según el caso, los daños o riesgos reales y probados, y no especulativos o imaginarios.

${ }^{17}$ Sentencia de la Corte Suprema de Justicia de Chile de 31 de mayo de 2004 (expediente de anexos a la demanda, tomo V, folio 2670).

${ }^{18}$ Resolución de la demanda de tuición provisoria por el Juzgado de Menores de Villarrica de 2 de mayo de 2003 (expediente de anexos a la demanda, tomo V, folio 2566).

${ }^{19}$ Cfr. Condición Jurídica y Derechos Humanos del Niño. Opinión Consultiva OC-17/02 de 28 de agosto de 2002. Serie A No. 17, párr. 56. En igual sentido, ver: Preámbulo de la Convención Americana. 
Por tanto, no pueden ser admisibles las especulaciones, presunciones, estereotipos o consideraciones generalizadas sobre características personales de los padres o preferencias culturales respecto a ciertos conceptos tradicionales de la familia.

110. - En conclusión, la Corte Interamericana observa que al ser, en abstracto, el «interés superior del niño» un fin legítimo, la sola referencia al mismo sin probar, en concreto, los riesgos o daños que podrían conllevar la orientación sexual de la madre para las niñas, no puede servir de medida idónea para la restricción de un derecho protegido como el de poder ejercer todos los derechos bumanos sin discriminación alguna por la orientación sexual de la persona ${ }^{20}$. El interés superior del niño no puede ser utilizado para amparar la discriminación en contra de la madre o el padre por la orientación sexual de cualquiera de ellos. De este modo, el juzgador no puede tomar en consideración esta condición social como elemento para decidir sobre una tuición o custodia.

111.- Una determinación a partir de presunciones infundadas y estereotipadas sobre la capacidad e idoneidad parental de poder garantizar y promover el bienestar y desarrollo del niño no es adecuada para garantizar el fin legítimo de proteger el interés superior del niño. La Corte considera que no son admisibles las consideraciones basadas en estereotipos por la orientación sexual, es decir, pre-concepciones de los atributos, conductas o características poseídas por las personas homosexuales o el impacto que estos presuntamente puedan tener en las niñas y los niños.»

Luego, se hace referencia a los argumentos que expone la Corte Suprema al momento de emitir su sentencia:

«113. - El Tribunal constata que la Corte Suprema de Justicia mencionó cuatro fundamentos directamente relacionados con la orientación sexual de la señora Atala: i) la presunta discriminación social que habrian sufrido las tres niñas por el ejercicio de la orientación sexual de la señora Atala; ii) la alegada confusión de roles que habrian presentando las tres niñas como consecuencia de la convivencia de su madre con una pareja del mismo sexo; iii) la supuesta prevalencia que la señora Atala le habría dado a su vida personal sobre los intereses de sus tres hijas, y iv) el derecho de las niñas a vivir en el seno de una familia con un padre y una madre. La Corte Suprema concluyó que los jueces recurridos fallaron en «no haber apreciado estrictamente en conciencia los antecedentes probatorios del

${ }^{20}$ En similar perspectiva, en un caso sobre el retiro de la custodia de una menor de edad por las creencias religiosas de la madre, el Tribunal Europeo de Derechos Humanos criticó la falta de prueba concreta y directa que demostrara el impacto que las creencias religiosas tenían en la crianza y en la vida diaria de los niños, por lo que consideró que el tribunal interno había fallado en abstracto y bajo el fundamento de consideraciones generales sin establecer una relación entre las condiciones de vida de los niños y de la madre. Cfr. T.E.D.H., Caso Palau-Martínez Vs. Francia (No. 64927/01), Sentencia de 16 de diciembre de 2003. Final, 16 de marzo de 2004, párrs. 42 y 43. 
proceso» y que al "haber preterido el derecho preferente de las menores (de edad) a vivir y desarrollarse en el seno de una familia estructurada normalmente y apreciada en el medio social, según el modelo tradicional que le es propio, hatbiant incurrido en falta o abuso grave, que deb (ía) ser corregido por la vía de acoger el (...) recurso de queja» ${ }^{21}$. La decisión de tuición provisoria utilizó como fundamento principal la supuesta prevalencia de intereses y el alegado derecho de las niñas a vivir en una familia tradicional (supra párr. 41), por lo que en estos puntos el examen se realizará de manera conjunta.

\subsubsection{Discriminación Social}

Se refiere entonces la sentencia de la $\mathrm{CIDH}$ a cada uno de los argumentos que esgrimió la Corte Suprema. En primer lugar, se hace cargo de la supuesta discriminación social que sufrirían las niñas producto del modo de vida de su madre y orientación sexual:

«115. - La Corte observa que entre los testimonios recabados en el proceso, una de las testigos manifestó que «se ha producido una discriminación en contra de las niñitas, pero no a nivel de (los\} niños, sino de los padres, quienes reprimen a los niños, no me consta que hayan hechos concretos de discriminación pero pusieron como ejemplo, que si se hacía una piyamada en la casa de (K)aren no le darian permiso a sus hijas para ir». Asimismo, algunos de los testigos indicaron que: i) "que las niñas van a ser discriminadas y afectadas en sus relaciones sociales»; ii) "en el ambiente del colegio y de sus pares (...) ellas están siendo señaladas, me preocupa que por vivir en (esta) ciudad tan pequeña, esta situación sea complicada», y iii) "los padres de los compañeros de colegio y (los) amiguitos toman actitudes de "protección" de sus hijos respecto de esta situación que la ven como contradictoria con la formación que ellos le proporcionan a sus hijos y eso necesariamente debe generar situaciones negativas y de aislamiento respecto a las niñitas, cosa que de acuerdo a lo me ban comentado lamentablemente está ocurriendo».

A este respecto, la Corte Interamericana de Derechos Humanos señala que la posibilidad de discriminación social no es un criterio válido para establecer diferencias, que tengan como fundamento la orientación sexual de las personas:

«115.- La Corte considera que, para justificar una diferencia de trato y la restricción de un derecho, no puede servir de sustento jurídico la alegada posibilidad de discriminación

${ }^{21}$ La Corte Suprema consideró que las condiciones descritas constituyen «causa calificada» de conformidad con el artículo 225 del Código Civil, para justificar la entrega de la tuición al padre, dado que la situación actual configuraba «un cuadro que irroga el riesgo de daños, los que podrían tornarse irreversibles, para los intereses de las menores, cuya protección debe preferir a toda otra consideración». Sentencia de la Corte Suprema de Justicia de Chile de 31 de mayo de 2004 (expediente de anexos a la demanda, tomo V, folios 2672 y 2673). 
social, probada o no, a la que se podrían enfrentar los menores de edad por condiciones de la madre o el padre. Si bien es cierto que ciertas sociedades pueden ser intolerantes a condiciones como la raza, el sexo, la nacionalidad o la orientación sexual de una persona, los Estados no pueden utilizar esto como justificación para perpetuar tratos discriminatorios. Los Estados están internacionalmente obligados a adoptar las medidas que fueren necesarias "para hacer efectivos» los derechos establecidos en la Convención, como se estipula en el articulo 2 de dicho instrumento interamericano por lo que deben propender, precisamente, por enfrentar las manifestaciones intolerantes y discriminatorias, con el fin de evitar la exclusión o negación de una determinada condición.

116.- El Tribunal constata que, en el marco de las sociedades contemporáneas se dan cambios sociales, culturales e institucionales encaminados a desarrollos más incluyentes de todas las opciones de vida de sus ciudadanos, lo cual se evidencia en la aceptación social de parejas interraciales, las madres o padres solteros o las parejas divorciadas, las cuales en otros momentos no habian sido aceptadas por la sociedad. En este sentido, el Derecho y los Estados deben ayudar al avance social, de lo contrario se corre el grave riesgo de legitimar y consolidar distintas formas de discriminación violatorias de los derechos humanos.

117. - Por otro lado, en cuanto al argumento de que el principio del interés superior del niño puede verse afectado por el riesgo de un rechazo por la sociedad, la Corte considera que un posible estigma social debido a la orientación sexual de la madre o el padre no puede considerarse un «daño» válido a los efectos de la determinación del interés superior del niño. Si los jueces que analizan casos como el presente constatan la existencia de discriminación social es totalmente inadmisible legitimar esa discriminación con el argumento de proteger el interés superior del menor de edad. En el presente caso, el Tribunal resalta que, además, la señora Atala no tenía por qué sufrir las consecuencias de que en su comunidad presuntamente las niñas podrian haber sido discriminadas debido a su orientación sexual.»

\subsubsection{Confusión de Roles}

A continuación, la sentencia de la CIDH se refiere a la supuesta confusión de roles en la que podrían incurrir las niñas, producto de las relaciones afectivas de la madre. En este sentido, se afirma que es el Estado quien debe demostrar que las conductas de los padres afectan negativamente el desarrollo de los niños:

«124. - Tratándose de la probibición de discriminación por orientación sexual, la eventual restricción de un derecho exige una fundamentación rigurosa y de mucho peso, invirtiéndose, además, la carga de la prueba, lo que significa que corresponde a la autoridad demostrar que su decisión no tenía un propósito ni un efecto discriminatorio. Esto es especialmente relevante en un caso como el presente, teniendo en cuenta que la determinación de un daño debe sustentarse en evidencia técnica y en dictámenes de expertos e investigadores en aras de establecer conclusiones que no resulten en decisiones discriminatorias. 
125. - En efecto, es el Estado el que tiene la carga de la prueba para mostrar que la decisión judicial objeto del debate se ha basado en la existencia de un daño concreto, específico y real en el desarrollo de las niñas. Para ello es necesario que en las decisiones judiciales sobre estos temas se definan de manera específica y concreta los elementos de conexidad y causalidad entre la conducta de la madre o el padre y el supuesto impacto en el desarrollo del niño. De lo contrario, se corre el riesgo de fundamentar la decisión en un estereotipo (supra párrs. 109 y 111) vinculado exclusivamente a la pre-concepción, no sustentada, de que los niños criados por parejas homosexuales necesariamente tendrían dificultades para definir roles de género o sexuales.»

Se afirma, a este respecto, que la Corte Suprema de Chile no cumplió con los requisitos de un test estricto, respecto de la causalidad entre la conducta de la madre y una supuesta afectación de las condiciones de desarrollo de las hijas.

«130. - El Tribunal observa que, en el presente caso, la Corte Suprema de Justicia de Chile no falló con base en un análisis in abstracto del alegado impacto de la orientación sexual de la madre en el desarrollo de las niñas ${ }^{22}$, sino que invocó la supuesta existencia de pruebas concretas. Sin embargo, se limitó en sus consideraciones a la aplicación de un test de daño especulativo limitándose a hacer referencia, respecto al supuesto daño, a la "eventual confusión de roles sexuales» y la «situación de riesgo para el desarrollo» de las niñas ${ }^{23}$. La Corte Suprema de Justicia afirmó la existencia de un «deterioro experimentado por el entorno social, familiar y educacional en que se desenv (olvía) la existencia de las menores» de edad, como consecuencia de la convivencia de la madre con su pareja, sin especificar en qué consistía la relación de causalidad entre dicha convivencia y el supuesto deterioro. No expuso argumentos para desvirtuar la posibilidad que el supuesto deterioro no se bubiera producido con ocasión de la nueva convivencia, sino como consecuencia de la separación anterior de la madre y el padre y los posibles efectos negativos que se podrían generar para las menores de edad. La Corte Suprema de Justicia tampoco se ocupó de exponer argumentos específicos para sustentar la situación familiar del padre como más favorable. La motivación de la Corte Suprema de Justicia se centró en los posibles daños psicológicos que podrían producirse en las tres niñas por el becho de vivir con una pareja homosexual, sin aludir a razones de suficiente peso que permitieran desvirtuar que la orientación sexual de la madre o el padre no tiene un efecto negativo para el bienestar psicológico y emocional, el desarrollo, la orientación sexual y las relaciones sociales del niño o la niña.

${ }^{22}$ La Corte Suprema hizo referencia a los testimonios de las empleadas domésticas sobre la supuesta confusión de roles experimentada por las niñas. $C f r$. Sentencia de la Corte Suprema de Justicia de Chile de 31 de mayo de 2004, considerado décimo quinto (expediente de anexos a la demanda, tomo V, folio 2672).

${ }^{23}$ Sentencia de la Corte Suprema de Justicia de Chile de 31 de mayo de 2004 (expediente de anexos a la demanda, tomo V, folio 2672). 
131. - La Corte Interamericana concluye que la Corte Suprema de Justicia no cumplió con los requisitos de un test estricto de análisis y sustentación de un daño concreto y específico supuestamente sufrido por las tres niñas a causa de la convivencia de su madre con una pareja del mismo sexo. Además, el Tribunal considera que, en el caso concreto, el becho de vivir con su madre y su pareja no privaba a las niñas del rol paterno, por cuanto el objeto del proceso de tuición no implicaba que el padre hubiera perdido el contacto con ellas.»

\subsubsection{Privilegio de Intereses (Derecho a la vida privada)}

Por otro lado, la Corte Interamericana de Derechos Humanos se refiere posteriormente, a la supuesta decisión de la Sra. Atala Riffo, de privilegiar sus intereses sobre el interés de las niñas.

Al respecto, la Corte afirma que el derecho a no ser discriminado por la opción sexual, no se limita a la condición determinada que se tenga, sino que también a la expresión (privada y pública) de la misma, ya que está conexa a la personalidad misma y su desarrollo libre:

«133.- La Corte Interamericana considera necesario recalcar que el alcance del derecho a la no discriminación por orientación sexual no se limita a la condición de ser homosexual, en sí misma, sino que incluye su expresión y las consecuencias necesarias en el proyecto de vida de las personas. Al respecto, en el Caso Laskey, Jaggard y Brown Vs. Reino Unido, el Tribunal Europeo de Derechos Humanos estableció que tanto la orientación sexual como su ejercicio son un aspecto relevante de la vida privada.»

«135.- El ámbito de protección del derecho a la vida privada ha sido interpretado en términos amplios por los tribunales internacionales de derechos humanos, al señalar que éste va más allá del derecho a la privacidad. Según el Tribunal Europeo, el derecho a la vida privada abarca la identidad física y social, el desarrollo personal y la autonomía personal de una persona, así como su derecho de establecer y desarrollar relaciones con otras personas y su entorno social, incluyendo el derecho de establecer y mantener relaciones con personas del mismo sexo. Además, el derecho a mantener relaciones personales con otros individuos, en el marco del derecho a la vida privada, se extiende a la esfera pública y profesional.

136. - En este sentido, la orientación sexual de una persona también se encuentra ligada al concepto de libertad y la posibilidad de todo ser humano de auto-determinarse y escoger libremente las opciones y circunstancias que le dan sentido a su existencia, conforme a sus propias opciones y convicciones. Por lo tanto, "(l) a vida afectiva con el cónyuge o compañera permanente, dentro de la que se encuentran, lógicamente, las relaciones sexuales, es uno de los aspectos principales de ese ámbito o círculo de la intimidad». 
De lo anterior se desprende, que no puede exigirse a la madre que posponga su propio proyecto de vida, que es fruto de su propia libertad, de la forma en cómo las sentencias lo hacen.

«139.- Al respecto, el Tribunal considera que dentro de la probibición de discriminación por orientación sexual se deben incluir, como derechos protegidos, las conductas en el ejercicio de la bomosexualidad. Además, si la orientación sexual es un componente esencial de identidad de la persona ${ }^{24}$, no era razonable exigir a la señora Atala que pospusiera su proyecto de vida y de familia. No se puede considerar como «reprochable o reprobable jurídicamente», bajo ninguna circunstancia, que la señora Atala baya tomado la decisión de rehacer su vida. Además, no se encontró probado un daño que baya perjudicado a las tres niñas.

140.- En consecuencia, la Corte considera que exigirle a la madre que condicionara sus opciones de vida implica utilizar una concepción "tradicional» sobre el rol social de las mujeres como madres, según la cual se espera socialmente que las mujeres lleven la responsabilidad principal en la crianza de sus hijos e bijas y que en pos de esto bubiera debido privilegiar la crianza de los niños y niñas renunciando a un aspecto esencial de su identidad. Por tanto, la Corte considera que bajo esta motivación del supuesto privilegio de los intereses personales de la señora Atala tampoco se cumplía con el objetivo de proteger el interés superior de las tres niñas.»

Finalmente, respecto de las justificaciones relativas al interés superior de las niñas, la Corte Interamericana se refiere al derecho a vivir en una familia normal y tradicional; asumiendo un giro copernicano:

«142.- La Corte constata que en la Convención Americana no se encuentra determinado un concepto cerrado de familia, ni mucho menos se protege sólo un modelo «tradicional» de la misma. Al respecto, el Tribunal reitera que el concepto de vida familiar no está reducido únicamente al matrimonio y debe abarcar otros lazos familiares de hecho donde las partes tienen vida en común por fuera del matrimonio ${ }^{25}$.

143.- En ello es coherente la jurisprudencia internacional. En el caso Salgueiro da Silva Mouta Vs. Portugal, el Tribunal Europeo consideró que la decisión de un tribunal nacional de retirar a un padre homosexual la custodia de su bija menor de edad, con el ar-

${ }^{24}$ Cfr. T.E.D.H., Caso Clift, supra nota 101, párr. 57 («Court has considered to constitute "other status" characteristics which, like some of the specific examples listed in the Article, can be said to be personal in the sense that they are innate or inherent. Thus in Salgueiro da Silva Mouta, [...] it found that sexual orientation was ['] 'undoubtedly covered['] by Article 14»).

${ }^{25}$ Opinión Consultiva OC-17/02, supra nota 122, párrs. 69 y 70 . Ver asimismo: T.E.D.H., Caso Keegan Vs. Irlanda (No. 16969/90), Sentencia de 26 de mayo de 1994, párr. 44, y Caso Kroon y otros Vs. Países Bajos (No. 18535/91), Sentencia de 27 de octubre de 1994, párr. 30. 
gumento que la niña debería vivir en una familia portuguesa tradicional, carecía de relación razonable de proporcionalidad entre la medida tomada (retiro de la custodia) y el fin perseguido (protección del interés superior de la menor de edad).

144. - Asimismo, el Tribunal Europeo de Derechos Humanos señaló en el Caso Karner Vs. Austria, que:

El objetivo de proteger la familia en el sentido tradicional es más bien abstracto y una amplia variedad de medidas concretas pueden utilizarse para implementarlo (...) como es el caso cuando hay una diferencia de trato basada en el sexo o en la orientación sexual, el principio de proporcionalidad no solamente requiere que la medida escogida sea, en principio, adecuada para el cumplimiento del objetivo buscado. También se debe demostrar que era necesario excluir a ciertas categorías de personas para lograr ese objetivo».

145. - En el presente caso, este Tribunal constata que el lenguaje utilizado por la Corte Suprema de Chile relacionado con la supuesta necesidad de las niñas de crecer en una "familia estructurada normalmente y apreciada en su medio social», y no en una "familia excepcional», refleja una percepción limitada y estereotipada del concepto de familia que no tiene base en la Convención al no existir un modelo específico de familia (la «familia tradicional»).

\subsubsection{Conclusión}

De todo lo anteriormente expuesto, se concluye lo siguiente:

«146. - Teniendo en cuenta todo lo anterior, este Tribunal concluye que si bien la sentencia de la Corte Suprema y la decisión de tuición provisoria pretendian la protección del interés superior de las niñas M., V. y R., no se probó que la motivación esgrimida en las decisiones fuera adecuada para alcanzar dicho fin, dado que la Corte Suprema de Justicia y el Juzgado de Menores de Villarrica no comprobaron en el caso concreto que la convivencia de la señora Atala con su pareja afectó de manera negativa el interés superior de las menores de edad (supra párr. 121, 131 y 139) y, por el contrario, utilizaron argumentos abstractos, estereotipados $y / 0$ discriminatorios para fundamentar la decisión (supra párr. 118, 119, 125, 130, 140 y 145), por lo que dichas decisiones constituyen un trato discriminatorio en contra de la señora Atala. Por tanto, la Corte declara que el Estado vulneró el derecho a la igualdad consagrado en el artículo 24 en relación con el artículo 1.1. de la Convención Americana, en perjuicio de Karen Atala Riffo.»

\subsection{Trato discriminatorio en contra de las niñas}

La sentencia de la $\mathrm{CIDH}$, posteriormente, se refiere al trato discriminatorio que habrían recibido las niñas, producto de las resoluciones de los tribunales 
chilenos. Se analiza entonces el alcance de los tratos discriminatorios a este respecto:

«150. - La Corte ya ha concluido que tanto la Sentencia de la Corte Suprema como la decisión del Juzgado de Menores de Villarrica, respecto a la tuición provisoria, constituyeron un trato discriminatorio en contra de la señora Atala (supra párr. 146), por lo que procederá a analizar si dicho trato generó una discriminación, a su vez, a las niñas $M ., V$. y $R$.. Al respecto, el Tribunal considera que la probibición de discriminación, en casos en que se relacionen menores de edad, debe ser interpretada a la luz del artículo 2 de la Convención sobre los Derechos del Niño, el cual establece que:

1. Los Estados Partes respetarán los derechos enunciados en la presente Convención y asegurarán su aplicación a cada niño sujeto a su jurisdicción, sin distinción alguna, independientemente de la raza, el color, el sexo, el idioma, la religión, la opinión política o de otra indole, el origen nacional, étnico o social, la posición económica, los impedimentos físicos, el nacimiento o cualquier otra condición del niño, de sus padres o de sus representantes legales.

2. Los Estados Partes tomarán todas las medidas apropiadas para garantizar que el niño se vea protegido contra toda forma de discriminación o castigo por causa de la condición, las actividades, las opiniones expresadas o las creencias de sus padres, o sus tutores o de sus familiares.

151.- Al respecto, la Corte resalta que las niñas y los niños no pueden ser discriminados en razón de sus propias condiciones y dicha probibición se extiende, además, a las condiciones de sus padres o familiares, como en el presente caso a la orientación sexual de la madre. En este sentido, el Comité de los Derechos del Niño ha aclarado en su Observación General No. 7 que los niños y las niñas pueden por ejemplo si han nacido fuera del matrimonio o en otras circunstancias que no se ajustan a los valores tradicionales ${ }^{26}$ sufrir las consecuencias de la discriminación de la cual son objeto sus padres»

Del examen de las circunstancias del caso, la Corte Interamericana de Derechos Humanos concluye que se ha producido una discriminación, no solo en contra de la madre, sino que también en contra de las niñas:

«154.- Al baber tomado como fundamento para su decisión la orientación sexual de la madre, la decisión de la Corte Suprema discriminó, a su vez, a las tres niñas, puesto que tomó en cuenta consideraciones que no habría utilizado si el proceso de tuición bubiera sido

${ }^{26}$ Cfr. Naciones Unidas, Comité de los Derechos del Niño, Observación General No. 7. Realización de los derechos del niño en la primera infancia, CRC/C/GC/7, 30 de septiembre de 2005, párr. 12. 
entre dos padres heterosexuales. En particular, la Corte reitera que el interés superior del niño es un criterio rector para la elaboración de normas y la aplicación de éstas en todos los órdenes relativos a la vida del niño.»

\section{DERECHO A LA VIDA PRIVADA Y DERECHO A LA VIDA FAMILIAR}

En primer lugar, la sentencia de la CIDH caracteriza la extensión del derecho a la vida privada, señalando:

«161.- El artículo 11 de la Convención probíbe toda injerencia arbitraria o abusiva en la vida privada de las personas, enunciando diversos ámbitos de la misma como la vida privada de sus familias. En ese sentido, la Corte ha sostenido que el ámbito de la privacidad se caracteriza por quedar exento e inmune a las invasiones o agresiones abusivas o arbitrarias por parte de terceros o de la autoridad pública.

162.- Además, el Tribunal ha precisado, respecto al artículo 11 de la Convención Americana, que, si bien esa norma se titula "Protección de la Honra y de la Dignidad», su contenido incluye, entre otros, la protección de la vida privada. La vida privada es un concepto amplio que no es susceptible de definiciones exhaustivas y comprende, entre otros ámbitos protegidos, la vida sexual y el derecho a establecer y desarrollar relaciones con otros seres humanos. Es decir, la vida privada incluye la forma en que el individuo se ve a sí mismo y cómo y cuándo decide proyectar a los demás.»

«164.- El Tribunal ha establecido en su jurisprudencia que el derecho a la vida privada no es un derecho absoluto y, por lo tanto, puede ser restringido por los Estados siempre que las injerencias no sean abusivas o arbitrarias. Por ello, las mismas deben estar previstas en ley, perseguir un fin legítimo y cumplir con los requisitos de idoneidad, necesidad y proporcionalidad, es decir, deben ser necesarias en una sociedad democrática.»

Luego, la sentencia considera que se pasó a llevar la privacidad de la Sra. Atala Riffo, desde el momento en que condición sexual, y el hecho de haber mantenido una relación lésbica estable, fue el elemento central en el análisis de su idoneidad como madre.

«167. - El Tribunal constata que durante el proceso de tuición, a partir de una visión estereotipada sobre los alcances de la orientación sexual de la señora Atala (supra párr. 146), se generó una injerencia arbitraria en su vida privada, dado que la orientación sexual es parte de la intimidad de una persona y no tiene relevancia para analizar aspectos relacionados con la buena o mala paternidad o maternidad. Por tanto, la Corte concluye que el Estado vulneró el artículo 11.2, en relación con el artículo 1.1. de la Convención Americana, en perjuicio de Karen Atala Riffo. 
168. - Por otra parte, el Tribunal observa que uno de los argumentos centrales que se analizaron en las decisiones de la Corte Suprema de Justicia y del Juzgado de Menores de Villarrica sobre la tuición provisoria fue la convivencia de la señora Atala con su pareja del mismo sexo (supra párrs. 41 y 56), por lo que esta Corte considera indispensable entrar a analizar la presunta violación a la vida familiar argumentada por la Comisión y los representantes.

169. - Al respecto, la Corte reitera que el artículo 11.2 de la Convención Americana está estrechamente relacionado con el derecho a que se proteja la familia y a vivir en ella, reconocido en el artículo 17 de la Convención, según el cual el Estado está obligado no sólo a disponer y ejecutar directamente medidas de protección de los niños, sino también a favorecer, de la manera más amplia, el desarrollo y la fortaleza del núcleo familiar. El Tribunal ha establecido que la separación de niños de su familia constituye, bajo ciertas condiciones, una violación del citado derecho, pues inclusive las separaciones legales del niño de su familia solo pueden proceder si están debidamente justificadas.

170.- En lo concerniente a los artículos 11.2 y 17.1. de la Convención Americana, el derecho de toda persona a recibir protección contra injerencias arbitrarias o ilegales en su familia, forma parte, implícitamente, del derecho a la protección de la familia, y además está expresamente reconocido por los artículos 12.1 de la Declaración Universal de los Derechos Humanos, $V$ de la Declaración Americana de Derechos y Deberes del Hombre, 17 del Pacto Internacional de Derechos Civiles y Políticos, y 8 del Convenio Europeo. Estas disposiciones poseen especial relevancia cuando se analiza la separación del niño de su familia.

171.- Según la jurisprudencia del Tribunal Europeo, el disfrute mutuo de la convivencia entre padres e hijos constituye un elemento fundamental de la vida de familia, y el artículo 8 del Convenio Europeo tiene como objetivo preservar al individuo contra las injerencias arbitrarias de las autoridades públicas y establecer obligaciones positivas a cargo del Estado a favor del respeto efectivo de la vida familiar.»

\section{GARANTÍAS JUDICIALES Y PROTECCIÓN JUDICIAL. QUEJA, TUTELA JUDICIAL Y LEGALIDAD}

En cuanto a este punto, se analiza la actuación de la Corte Suprema, en el conocimiento del recurso de queja, que terminó con la revocación de la sentencia de la Corte de Apelaciones de Temuco. Así, en primer lugar, en un verdadero obiter dicta la sentencia de la $\mathrm{CIDH}$ analiza al recurso de queja y su relación con la independencia judicial:

«183. - Al respecto, la Corte observa que el alegato de los representantes sobre la aceptación indebida del recurso de queja por la Corte Suprema de Justicia está directamente 
relacionado con la presunta inexistencia de una falta grave por parte de la Corte de Apelaciones de Temuco. Al respecto, cabe señalar que el recurso de queja en Chile se encuentra previsto en el artículo 545 del Código Orgánico de Tribunales. Es un recurso disciplinario que tiene su fuente en el artículo 82 de la Constitución y, en general, encuentra su origen en la práctica jurisprudencial de los Tribunales Superiores de Justicia, las Cortes de Apelaciones y la Corte Suprema de Justicia.»

«185.- De otra parte, la Corte observa que, según la doctrina jurídica chilena remitida por el Estado, el recurso de queja es definido como «el acto jurídico procesal de parte que se ejerce directamente ante el Tribunal superior jerárquico y en contra del juez o jueces inferiores que dictaron en un proceso del cual conocen una resolución con falta o abuso grave, solicitándole que ponga pronto remedio al mal que motiva su interposición mediante la enmienda, revocación o invalidación de aquélla, sin perjuicio de la aplicación de las sanciones disciplinarias que fueren procedentes por el pleno de ese Tribunal respecto del juez o jueces recurridos». Dicho recurso se interpone "directamente ante el Tribunal superior jerárquico de aquel que bubiere dictado la resolución con falta o abuso grave, para que sea conocido y resuelto por el mismo». No se interpone en contra de una resolución, sino contra el juez o los jueces que dictaron la resolución con falta o abuso grave, para que ésta sea modificada, enmendada o dejado sin efecto. El recurso no ha sido «creado para corregir simples errores de interpretación, sino faltas o abusos ministeriales (...) que caigan dentro del ámbito de (l)a jurisdicción disciplinaria del superior jerárquico». Por lo tanto, "no constituye instancia para la revisión de todas las cuestiones de becho y de derecho, sino que únicamente faculta al superior de examinar si se cometió la falta o abuso grave». El tribunal superior queda facultado para la revocación, enmienda o invalidación de la resolución. La falta o abuso grave cometido por un juez puede derivar de la contravención formal de la ley, la interpretación errada de la ley o la falsa apreciación de los antecedentes del proceso.

186. - Para analizar si en el presente caso se desconoció la garantía de independencia judicial al aceptar el recurso de queja, la Corte recuerda que uno de los objetivos principales que tiene la separación de los poderes públicos, es la garantía de la independencia de los jueces, cuyo objetivo radica en evitar que el sistema judicial y sus integrantes se vean sometidos a restricciones indebidas en el ejercicio de su función por parte de órganos ajenos al $P_{0-}$ der Judicial o incluso por parte de aquellos magistrados que ejercen funciones de revisión o apelación. Además, la garantía de la independencia judicial abarca la garantía contra presiones externas, de tal forma que el Estado debe abstenerse de realizar injerencias indebidas en el Poder Judicial o en sus integrantes, es decir, con relación a la persona del juez específico, $y$ debe prevenir dichas injerencias e investigar y sancionar a quienes las cometan.»

Se analiza posteriormente, la extensión de la exigencia de independencia judicial, y el principio de imparcialidad de los jueces, señalándose:

«189. - De otra parte, respecto a la presunta imparcialidad de la Corte Suprema al adoptar su decisión sobre el recurso de queja, esta Corte recuerda que la imparcialidad exi- 
ge que el juez que interviene en una contienda particular se aproxime a los hechos de la causa careciendo, de manera subjetiva, de todo prejuicio $y$, asimismo, of reciendo garantías suficientes de indole objetiva que permitan desterrar toda duda que el justiciable o la comunidad puedan albergar respecto de la ausencia de imparcialidad. Mientras que la imparcialidad personal o subjetiva se presume a menos que exista prueba en contrario, consistente por ejemplo en la demostración de que algún miembro de un tribunal o juez guarda prejuicios o parcialidades de indole personal contra los litigantes, la denominada prueba objetiva consiste en determinar si el juez cuestionado brindó elementos convincentes que permitan eliminar temores legítimos o fundadas sospechas de parcialidad sobre su persona. Ello puesto que el juez debe aparecer como actuando sin estar sujeto a influencia, aliciente, presión, amenaza o intromisión, directa o indirecta ${ }^{27}$, sino única y exclusivamente conforme a -y movido por- el Derecho.»

Finalmente, la Corte considera que no se han aportado antecedentes que permitan concluir que se ha vulnerado la imparcialidad, ni objetiva ni subjetiva, por parte de los tribunales chilenos:

«191.- El Tribunal constata que ni la Comisión ni los representantes han aportado elementos probatorios específicos para desvirtuar la presunción de imparcialidad subjetiva de los jueces. Tampoco se ban aportado elementos convincentes que permitan cuestionar la imparcialidad objetiva de los jueces en la sentencia de la Corte Suprema. Una interpretación de las normas del Código Civil chileno en forma contraria a la Convención Americana en materia del ejercicio de la custodia de menores de edad por una persona bomosexual no es suficiente, en sí misma, para declarar por este Tribunal una falta de la imparcialidad objetiva.

192. - En consecuencia, la Corte considera que el Estado no violó las garantías judiciales reconocidas en el artículo 8.1 de la Convención en relación con la decisión de la Corte Suprema de Justicia en el presente caso. »

\section{DERECHO DE LAS NIÑAS A SER ESCUCHADAS}

Tal como se hace en los puntos anteriores, lo primero que hace la sentencia de la CIDH es especificar el contenido del derecho que se analiza engarzado en las garantías de la tutela judicial, estableciendo:

«196. - La Corte resalta que los niños y las niñas son titulares de los derechos establecidos en la Convención Americana, además de contar con las medidas especiales de protección contempladas en el artículo 19 de la Convención, las cuales deben ser definidas según

${ }^{27}$ Principio 2 de los Principios Básicos de las Naciones Unidas relativos a la Independencia de la Judicatura, supra nota 212. 
las circunstancias particulares de cada caso concreto. En el presente caso, el Tribunal observa que el artículo 8.1 de la Convención Americana consagra el derecho a ser oído que ostentan todas las personas, incluidos los niños y niñas, en los procesos en que se determinen sus derechos. Dicho derecho debe ser interpretado a la luz del artículo 12 de la Convención sobre los Derechos del Niño, el cual contiene adecuadas previsiones sobre el derecho a ser escuchado de las niñas y los niños, con el objeto de que la intervención del niño se ajuste a las condiciones de éste y no redunde en perjuicio de su interés genuino.

197.- De manera específica, la Observación General No. 12 de 2009 del Comité de los Derechos del Niño de Naciones Unidas resaltó la relación entre el «interés superior del niño» y el derecho a ser escuchado, al afirmar que «no es posible una aplicación correcta del artículo 3 \{(interés superior del niño)\} si no se respetan los componentes del artículo 12. Del mismo modo, el artículo 3 refuerza la funcionalidad del artículo 12 al facilitar el papel esencial de los niños en todas las decisiones que afecten su vida».

198.- Con el fin de determinar los alcances de los términos descritos en el artículo 12 de dicha Convención, el Comité realizó una serie de especificaciones, a saber: i) "no puede partir(se) de la premisa de que un niño es incapaz de expresar sus propias opiniones»; ii) «el niño no debe tener necesariamente un conocimiento exhaustivo de todos los aspectos del asunto que lo afecta, sino una comprensión suficiente para ser capaz de formarse adecuadamente un juicio propio sobre el asunto»; iii) el niño puede expresar sus opiniones sin presión y puede escoger si quiere o no ejercer su derecho a ser escuchado; iv) "la realización del derecho del niño a expresar sus opiniones exige que los responsables de escuchar al niño y los padres o tutores informen al niño de los asuntos, las opciones y las posibles decisiones que pueden adoptarse y sus consecuencias»; v) «la capacidad del niño (...) debe ser evaluada para tener debidamente en cuenta sus opiniones o para comunicar al niño la influencia que han tenido esas opiniones en el resultado del proceso», y vi) «los niveles de comprensión de los ninos no van ligados de manera uniforme a su edad biológica», por lo que la madurez de los niños o niñas debe medirse a partir de «la capacidad (...) para expresar sus opiniones sobre las cuestiones de forma razonable e independiente».

199.- Por otra parte, la Corte reitera que los niños y las niñas ejercen sus derechos de manera progresiva a medida que desarrollan un mayor nivel de autonomía personal (supra párr. 108). En consecuencia, el aplicador del derecho, sea en el ámbito administrativo o en el judicial, deberá tomar en consideración las condiciones específicas del menor de edad y su interés superior para acordar la participación de éste, según corresponda, en la determinación de sus derechos. En esta ponderación se procurará el mayor acceso del menor de edad, en la medida de lo posible, al examen de su propio caso. Asimismo, la Corte considera que las niñas y los niños deben ser informados de su derecho a ser escuchados directamente o por medio de un representante, si así lo desean. Al respecto, en casos en que se presenten conflictos de intereses entre la madre y el padre, es necesario que el Estado garantice, en lo posible, que los intereses del menor de edad sean representados por alguien ajeno a dicho conflicto. 
200. - En este sentido, el Comité de los Derechos del Niño ha señalado que el artículo 12 de la Convención sobre los Derechos del Niño no sólo establece el derecho de cada niño de expresar su opinión libremente en todos los asuntos que lo afectan, sino el artículo abarca también el subsiguiente derecho de que esas opiniones se tengan debidamente en cuenta, en función de la edad y madurez del niño. No basta con escuchar al niño, las opiniones del niño tienen que tomarse en consideración seriamente a partir de que el niño sea capaz de formarse un juicio propio, lo que requiere que las opiniones del niño sean evaluadas mediante un examen caso por caso. Si el niño está en condiciones de formarse un juicio propio de manera razonable e independiente, el encargado de adoptar decisiones debe tener en cuenta las opiniones del niño como factor destacado en la resolución de la cuestión ${ }^{28}$. Por tanto, en el contexto de decisiones judiciales sobre la custodia, toda la legislación sobre separación y divorcio debe incluir el derecho del niño a ser escuchado por los encargados de adoptar decisiones.»

Posteriormente, se consigna en la sentencia de la CIDH la obligación de los tribunales de escuchar a los niños:

«206. - Sin embargo, el hecho de que una autoridad judicial no tenga que recabar nuevamente el testimonio a un niño o niña en el marco de un proceso judicial, no la libera de la obligación de tener debidamente en cuenta y valorar, en un sentido u otro, las opiniones expresadas por la niña y el niño en las instancias inferiores, en función de la edad y capacidad del niño. De ser pertinente, la autoridad judicial respectiva debe argumentar específicamente por qué no va a tomar en cuenta la opción del niño o la niña. En este sentido, el perito García Méndez expresó que:

En cualquier tipo de controversia entre la opinión de los niños y la autoridad parental o las autoridades institucionales, (...) la opinión de los niños no puede ser descartada discrecionalmente. Es decir, lo que significa esto es que (...) hay que construir en forma muy sofisticada, argumentos para eventualmente oponerse a lo que sea esta opinión de los niños. (L) a opinión de los niños automáticamente no produce jurisprudencia (...). Pero también la opinión de los niños no puede ser descartada automáticamente sin una argumentación seria y profunda»

En conclusión, se sostiene en la sentencia de la CIDH que la Corte Suprema violó el derecho de las niñas a ser escuchadas, al no haber valorado las declaraciones que ya habían prestado a lo largo del juicio:

«208. - La Corte constata que la Corte Suprema de Justicia no explicó en su sentencia cómo evaluó o tomó en cuenta las declaraciones y preferencias hechas por las menores de edad que constaban en el expediente. En efecto, el Tribunal observa que la Corte Suprema no

${ }^{28}$ Cfr. Comité de los Derechos del Niño, Observación General No. 12, supra nota 218, párr. 44. 
adoptó una decisión en la que se razonara sobre la relevancia atribuida por dicha Corte a las preferencias de convivencia expresadas por las menores de edad y las razones por las cuales se apartaba de la voluntad de las tres niñas. Por el contrario, la Corte Suprema se limitó a fundamentar su decisión en el supuesto interés superior de las tres menores de edad pero sin motivar o fundamentar la razón por la que consideraba legítimo contradecir la voluntad expresada por las niñas durante el proceso de tuición, más aún si se tiene en cuenta la interrelación entre el derecho a participar de los niños y niñas y el objetivo de cumplir con el principio del interés superior del niño (supra párr. 197). Por lo anteriormente indicado, la Corte concluye que la referida decisión de la Corte Suprema de Justicia violó el derecho a ser oídas de las niñas y ser debidamente tomadas en cuenta consagrado en el artículo 8.1, en relación con los artículos 19 y 1.1 de la Convención Americana en perjuicio de las niñas M., V. y R..»

\section{OBLIGACIÓN DE RESPETAR Y GARANTIZAR EL DERECHO A LA IGUALDAD, A LA PROHIBICIÓN DE DISCRIMINACIÓN, A LA VIDA PRIVADA Y A LAS GARANTÍAS JUDICIALES, RESPECTO DE LA INVESTIGACIÓN DISCIPLINARIA}

Se señala, como el objeto de este apartado de la sentencia de la CIDH el siguiente:

«209. - Uno de los aspectos de la controversia es el proceso disciplinario llevado a cabo en contra de la señora Atala. En lo que atañe a ese tema, en el presente capitulo se establecerán los hechos probados relacionados con dicho proceso para luego analizar las controversias en torno a: i) derecho a la igualdad; ii) vida privada, y iii) garantías judiciales.»

\subsection{Derecho a la Igualdad y Probibición de la Discriminación}

Se señala a este respecto, que el procedimiento disciplinario, llevado a cabo por la Corte de Apelaciones de Temuco, que tuvo lugar durante la sustanciación del juicio, habría incurrido en un trato diferenciado respecto de la Sra. Atala Riffo, por su condición sexual:

«218. - El Tribunal nota que la Corte de Apelaciones de Temuco recibió el 17 de marzo de 2003 una denuncia contra la señora Atala por el uso de implementos y personal del Juzgado para asuntos de interés personal (supra párr. 210). Sin embargo, la Corte observa que, de acuerdo con lo plasmado en el informe del ministro visitador, se expresaron otras consideraciones para llevar a cabo la visita al sitio de trabajo de la señora Atala. Ellas estaban expresamente referidas a su orientación sexual, pues se relacionaban con "las publicaciones aparecidas en el diario "La Cuarta" de fecha 28 de febrero de (2003) y en "Las 
Últimas Noticias' de fecha 1 de marzo (de 2003), en las cuales se di ió) a conocer a la opinión pública el contenido de una demanda de tuición entablada por el (señor López) en contra de su esposa (...) porque esta última sostendría una relación lésbica con otra mujer». De manera que uno de los motivos de la visita al sitio de trabajo de la señora Atala era constatar lo manifestado por las publicaciones de prensa respecto a su orientación sexual.

219.- La Corte observa que la investigación disciplinaria y la visita extraordinaria mencionadas tienen fundamento legal en los artículos 544 inciso 4, 559 y 560 del Código Orgánico de Tribunales. Al ser uno de los propósitos de la visita el indagar sobre la orientación sexual de la señora Atala con base en las noticias de prensa, se constata un trato diferenciado en perjuicio de la señora Atala al incorporar como materia investigable en el proceso disciplinario su orientación sexual y su relación con una persona del mismo sexo.»

\section{(...)}

«221.- Abora bien, respecto al fin legítimo que se perseguía con dicha investigación, en el informe presentado no fue precisado con claridad cuál era el fin de la visita respecto a la indagación de la orientación sexual, por cuanto sólo se hizo referencia a las noticias de prensa que se habian publicado. En este sentido, si bien el fin legítimo no fue explicitado en el reporte, de lo expresado en el informe se podría llegar a inferir que mediante la indagación respecto a la orientación sexual de la señora Atala se buscaba proteger la «imagen del poder judicial». Sin embargo, la alegada protección de la «imagen del poder judicial» no puede justificar una diferencia de trato basada en la orientación sexual. Además, el fin que se invoque al efectuar una diferencia de trato de este tipo debe ser concreto y no abstracto. En el caso concreto, el Tribunal no observa relación alguna entre un deseo de proteger la «imagen del poder judicial» y la orientación sexual de la señora Atala. La orientación sexual o su ejercicio no pueden constituir, bajo ninguna circunstancia, fundamento para llevar a cabo un proceso disciplinario, pues no existe relación alguna entre el correcto desempeño de la labor profesional de la persona y su orientación sexual.

222.- Por tanto, al ser discriminatoria una diferenciación en una indagación disciplinaria relacionada con su orientación sexual, la Corte concluye que el Estado vulneró el artículo 24 en relación con el artículo 1.1 de la Convención Americana en perjuicio de Karen Atala Riffo.»

\subsection{Derecho a la Vida Privada}

En este punto, la sentencia de la CIDH estima que se violó la vida privada de la Sra. Atala Riffo, puesto que si bien, no se impusieron sanciones disciplinarias por la circunstancia de ser ella lesbiana, si se realizaron investigaciones al respecto, cuestión que se aparta de cuestiones profesionales o funcionarias. 
«228. - Además, la señora Atala explicó que, antes de la visita extraordinaria, la Corte de Apelaciones de Temuco le habia dirigido a los funcionarios del Juzgado de Villarrica un cuestionario con preguntas para indagar sobre la orientación sexual de la señora Atala. Estos hechos no fueron controvertidos por el Estado.

229. - En particular, la Corte nota que en el informe de la visita del señor Lillo se establecieron, como conclusión, entre otros, los siguientes hechos: i) que la señora Atala «comenzó a ser visitada en su oficina por una gran cantidad de mujeres a partir de mediados del 2002 ${ }^{29}$, incluyendo a su pareja "con quien pasaba horas en su oficina»; ii) que la señora Atala "fue visitada en el Tribunal por los padres» de su pareja y que informó que «se trataba (n) de sus suegros», y iii) que la señora Atala «manifestó su homosexualidad abiertamente» al señor Lillo y "defendió su determinación de comunicárselo abiertamente a los funcionarios y Magistrados del Tribunal».

230. - La Corte constata que, si bien la investigación disciplinaria se inició con un fundamento legal y no terminó con una sanción disciplinaria en contra de la señora Atala por su orientación sexual, sí se indagó en forma arbitraria sobre ello, lo cual constituye una interferencia al derecho a la vida privada de la señora Atala, el cual se extendía a su ámbito profesional. Por lo tanto, el Estado es responsable por la violación del derecho a la vida privada, reconocido en el artículo 11.2 en relación con el artículo 1.1 de la Convención Americana, en perjuicio de Karen Atala Riffo.»

\subsection{Garantías Judiciales}

En cuanto a las garantías judiciales, la CIDH, estima que no se actuó con imparcialidad en el procedimiento disciplinario que tuvo lugar, puesto que el mismo estuvo motivado por el prejuicio y no por motivos legítimos, así se expresa:

«235. - La Corte ya ha establecido (supra párrs. 222 y 230) que la visita extraordinaria afectó el derecho a la igualdad y a la no discriminación y la vida privada de la senora Atala. Asimismo, se ha concluido que era discriminatorio incorporar en la investigación disciplinaria la orientación sexual o la relación de pareja de la señora Atala, por cuanto no existía relación alguna con su desempeño profesional (supra párr. 221) y por lo cual tampoco existía fundamento para concluir que la orientación sexual de la señora Atala podía derivar en una falta disciplinaria. Sin embargo, en el informe de la visita al si-

${ }^{29}$ Informe preparado por el Ministro Lenin Lillo de la Corte de Apelaciones de Temuco de 2 de abril de 2003, supra nota 43, folio 5933.

(C) UNED. Revista de Derecho Político 
tio de trabajo se determinó, con relación a la orientación sexual de la señora Atala, que los hallazgos eran hechos que "rev(estian) una gravedad que merectia) ser observada por (la Corte de Apelaciones de Temuco)» (supra párr. 214).

236. - Además, el Tribunal toma en cuenta las circunstancias de la realización de la visita extraordinaria, ya que antes y durante la visita se llevaron a cabo una serie de interrogatorios a funcionarios y empleados del Juzgado de Villarrica para indagar sobre la orientación sexual y los hábitos de la señora Atala (supra párrs. 228 y 229). También se observa que las conclusiones del informe de la visita presentadas a la Corte de Apelaciones, en su conjunto, fueron aprobadas por dicha Corte el mismo día que fue presentado dicho informe. La Corte de Apelaciones procedió entonces a imputarle cargos disciplinarios a la señora Atala, entre otras cosas, por su orientación sexual (supra párr. 215).

237.- Teniendo en cuenta todos los hechos reseñados anteriormente, la Corte considera que existían prejuicios y estereotipos que fueron manifestados en el informe, que demostraban que quienes realizaron y aprobaron dicho informe no fueron objetivos respecto a este punto. Por el contrario, dejaron plasmada su posición personal respecto a la orientación sexual de la señora Atala en un ámbito disciplinario en el que no era aceptable ni legítimo un reproche jurídico por este hecho. En consecuencia, la Corte establece que la visita extraordinaria y la investigación disciplinaria se realizaron sin la imparcialidad subjetiva necesaria, por lo que el Estado vulneró el artículo 8.1 en relación con el artículo 1.1 de la Convención Americana en perjuicio de Karen Atala Riffo.»

Además, la sentencia de la CIDH hace una referencia a las obligaciones de los jueces en relación con la imparcialidad necesaria para resolver un asunto:

«238. - En relación al Ministro Loyola, la Corte observa que en el expediente no consta prueba con la que se pudiera corroborar que el señor Loyola, en una reunión privada que se babría llevado a cabo en marzo de 2003, le bubiera sugerido a la señora Atala que entregara sus hijas al padre de las mismas. Por otra parte, el Tribunal reitera que la garantía a la imparcialidad judicial debe ser respetada por las autoridades judiciales de manera ex oficio. Por lo tanto, cualquier juez, al respecto del cual exista una razón legítima y objetiva para poner en duda su imparcialidad, debe inbibirse de participar en la adopción de la decisión ${ }^{30}$. Por lo anterior, el señor Lillo debió apartarse de la decisión de no innovar de 24 de noviembre de 2003, después de haber llevado a cabo la visita ex-

${ }^{30}$ Cfr. T.E.D.H., Caso Micallef Vs. Malta (No. 17056/06), G.C., Sentencia del 15 de octubre de 2009, párr. 98 («What is at stake is the confidence which the courts in a democratic society must inspire in the public. Thus, any judge in respect of whom there is a legitimate reason to fear a lack of impartiality must withdraw»); T.E.D.H., Caso Castillo Algar Vs. España (No. 28194/95), Sentencia de 8 de octubre de 1998, párr. 45. 
traordinaria en el marco de la investigación disciplinaria. No obstante, la Corte constata que inmediatamente después de dicha decisión la Corte de Apelaciones de Temuco decidió confirmar las consideraciones de la primera instancia y dejar sin efecto dicha orden de no innovar.»

\section{REPARACIONES}

En atención a que la sentencia de la $\mathrm{CIDH}$ estima que se han producido violaciones a obligaciones internacionales, deben decretarse medidas de reparación, de acuerdo a lo que se expone:

«239.- Sobre la base de lo dispuesto en el artículo 63.1 de la Convención Americana, la Corte ha indicado que toda violación de una obligación internacional que haya producido daño comporta el deber de repararlo adecuadamente, y que esa disposición recoge una norma consuetudinaria que constituye uno de los principios fundamentales del Derecho Internacional contemporáneo sobre responsabilidad de un Estado.»

En cuanto al tipo y entidad de las reparaciones, se señala:

«241.- La reparación del daño ocasionado por la infracción de una obligación internacional requiere, siempre que sea posible, la plena restitución (restitutio in integrum), que consiste en el restablecimiento de la situación anterior. De no ser esto factible, como ocurre en la mayoría de los casos de violaciones a derechos humanos, el Tribunal determinará medidas para garantizar los derechos conculcados, reparar las consecuencias que las infracciones produjeron y establecer una indemnización que compense los daños ocasionados. Por tanto, la Corte ha considerado la necesidad de otorgar diversas medidas de reparación, a fin de resarcir los daños de manera integral, por lo que además de las compensaciones pecuniarias, las medidas de restitución, satisfacción y garantias de no repetición tienen especial relevancia por los daños ocasionados.

242.- Este Tribunal ha establecido que las reparaciones deben tener un nexo causal con los hechos del caso, las violaciones declaradas, los daños acreditados, así como con las medidas solicitadas para reparar los daños respectivos. Por tanto, de acuerdo con las consideraciones expuestas sobre el fondo y las violaciones a la Convención declaradas en los capítulos anteriores, la Corte deberá observar dicha concurrencia para pronunciarse debidamente y conforme a derecho.

243. - El Tribunal considera parte lesionada, en los términos del artículo 63.1 de la Convención, a quien ha sido declarado víctima de la violación de algún derecho consagrado en la misma. En el caso bajo examen la Corte declaró que el Estado violó los derechos bumanos de Karen Atala Riffo y las niñas M., V. y R. (supra párrs. 146, 155, 178, 208, 
222, 230 y 237). En lo que atañe a la niña V., a los efectos de las reparaciones, se debe estar a lo establecido en el párrafo 71.»

En cuanto a las formas de reparación, se establece que la sentencia es per se, una forma de reparar los daños, pero que ella no excluye a otras:

«246.- La jurisprudencia internacional y, en particular, de la Corte Interamericana, ha establecido reiteradamente que la sentencia constituye per se una forma de reparación. No obstante, considerando las circunstancias del presente caso, y las afectaciones a las víctimas derivadas de las violaciones de los artículos 24, 11.2, 17.1, 19, 8.1 y 1.1 de la Convención Americana, declaradas en perjuicio de la señora Atala y las niñas M., V. y R., la Corte estima pertinente fijar algunas medidas de reparación según se explica en los siguientes apartados.»

Se refiere la sentencia a medidas de rehabilitación desde un punto de vista psicológico, estableciendo reparaciones al respecto:

«254. - La Corte estima, como lo ha hecho en otros casos, que es preciso disponer una medida de reparación que brinde una atención adecuada a los padecimientos psicológicos sufridos por las víctimas, atendiendo a sus especificidades. Por lo tanto, habiendo constatado las violaciones y los daños sufridos por las víctimas en el presente caso, el Tribunal dispone la obligación a cargo del Estado de brindarles gratuitamente y de forma inmediata, hasta por cuatro años, el tratamiento médico y psicológico que requieran. En particular, el tratamiento psicológico debe brindarse por personal e instituciones estatales especializadas en la atención de víctimas de bechos como los ocurridos en el presente caso. Al proveer dicho tratamiento se deben considerar, además, las circunstancias y necesidades particulares de cada víctima, de manera que se les brinden tratamientos familiares e individuales, según lo que se acuerde con cada una de ellas, después de una evaluación individual. Los tratamientos deben incluir la provisión de medicamentos y, en su caso, transporte y otros gastos que estén directamente relacionados y sean estrictamente necesarios.»

De la misma forma, se dispone la realización de acciones de reconocimiento de responsabilidad en las violaciones a las obligaciones internacionales de derechos humanos:

«263. - La Corte ba determinado que en ciertos casos se justifica que los Estados realicen un reconocimiento de responsabilidad que debe realizarse en un acto público para que surta sus efectos plenos ${ }^{31}$. En el presente caso procede adoptar una medida de dicha naturaleza y el Estado deberá hacer referencia a las violaciones de derechos humanos declaradas en la presente Sentencia. El Estado deberá asegurar la participación de las víctimas que así lo

${ }^{31}$ Cfr. Caso Cantoral Benavides Vs. Perú. Reparaciones y Costas. Sentencia de 3 de diciembre de 2001. Serie C No. 88, párr. 81 y Caso de la Masacre de Pueblo Bello Vs. Colombia. Fondo, Reparaciones y Costas. Sentencia de 31 de enero de 2006. Serie C No. 140, párr. 254. 
deseen, e invitar al evento a las organizaciones que representaron a las víctimas en las instancias nacionales e internacionales. La realización y demás particularidades de dicha ceremonia pública deben consultarse previa y debidamente con los representantes de las víctimas. Para cumplir con esta obligación el Estado cuenta con un plazo de un año a partir de la notificación de la presente Sentencia.

264.- En cuanto a las autoridades estatales que deberán estar presentes o participar en dicho acto, el Tribunal, como lo ha hecho en otros casos, señala que deberán ser de alto rango. Corresponderá al Estado definir a quienes se encomienda tal tarea. Sin embargo, deberá existir representación del Poder Judicial en el acto.»

Por otro lado, se consideran las medidas que pueden adoptarse, y que tiendan a la no repetición de las conductas de discriminación que han sido objeto de esta sentencia:

«267. - La Corte resalta que algunos actos discriminatorios analizados en capítulos previos se relacionaron con la reproducción de estereotipos que están asociados a la discriminación estructural e histórica que han sufrido las minorías sexuales (supra párr. 92), particularmente en cuestiones relacionadas con el acceso a la justicia y la aplicación del derecho interno. Por ello, algunas de las reparaciones deben tener una vocación transformadora de dicha situación, de tal forma que las mismas tengan un efecto no solo restitutivo sino también correctivo ${ }^{32}$ hacia cambios estructurales que desarticulen aquellos estereotipos y prácticas que perpetuan la discriminación contra la población LGTBI. En esta línea a continuación se analizarán las solicitudes de la Comisión y los representantes.»

Específicamente, respecto de las acciones que se orienten a la no repetición de las conductas, se señala:

«271.- El Tribunal toma nota de los desarrollos llevados a cabo por el Estado en materia de programas y acciones de capacitación dirigidos a capacitar a funcionarios públicos. Sin perjuicio de lo anterior, la Corte ordena que el Estado continúe implementando programas y cursos permanentes de educación y capacitación en: i) derechos bumanos, orientación sexual y no discriminación; ii) protección de los derechos de la comunidad LGBTI, y iii) discriminación, superación de estereotipos de género en contra de la población LGTBI. Los cursos deben estar dirigidos a funcionarios públicos a nivel regional y nacional, y particularmente a funcionarios judiciales de todas las áreas y escalafones de la rama judicial.

272. - Dentro de dichos programas y cursos de capacitación deberá hacerse una especial mención a la presente Sentencia y a los diversos precedentes del corpus iuris de los derechos bumanos relativos a la proscripción de la discriminación por orientación sexual y a la obli-

\footnotetext{
${ }^{32}$ En similar sentido, cfr. Caso González y otras («Campo Algodonero»), supra nota 127, párr. 450.
} 
gación de todas las autoridades y funcionarios de garantizar que todas las personas, sin discriminación por su orientación sexual, puedan gozar de todos y cada uno de los derechos establecidos en la Convención. Debe ponerse especial atención para este efecto, en normas o prácticas en el derecho interno que, sea intencionalmente o por sus resultados, pueden tener efectos discriminatorios en el ejercicio de derechos por personas pertenecientes a las minorías sexuales.»

En cuanto a las adecuaciones del derecho interno, se señala en primer lugar, que permitan concluir que la violación de la Convención derivó de un problema de las normas internas en sí mismas.

«279. - La Corte recuerda que el artículo 2 de la Convención obliga a los Estados Parte a adoptar, con arreglo a sus procedimientos constitucionales y a las disposiciones de la Convención, las medidas legislativas o de otro carácter que fueren necesarias para hacer efectivos los derechos y libertades protegidos por la Convención ${ }^{33}$. Es decir, los Estados no sólo tienen la obligación positiva de adoptar las medidas legislativas necesarias para garantizar el ejercicio de los derechos en ella consagrados, sino que también deben evitar promulgar aquellas leyes que impidan el libre ejercicio de estos derechos, y evitar que se supriman o modifiquen las leyes que los protegen ${ }^{34}$.

280. - En el presente caso, la Corte se limitó a examinar la relación entre la aplicación judicial de ciertas normas con prácticas discriminatorias. El Tribunal no analizó la compatibilidad de una determinada norma con la Convención Americana ni fue ello materia de este caso. Asimismo, los representantes no aportaron elementos suficientes que permitan inferir que las violaciones se hayan derivado de un problema de las leyes en si mismas. Por tanto, la Corte considera que no es pertinente, en las circunstancias del presente caso, ordenar la adopción, modificación o adecuación de normas específicas de derecho interno.»

Además, se hace una referencia a la obligación de los jueces respecto del control de convencionalidad de normas internas.

«281. - De otra parte, conforme lo ha establecido en su jurisprudencia previa, este Tribunal recuerda que es consciente que las autoridades internas están sujetas al imperio de la ley y, por ello, están obligadas a aplicar las disposiciones vigentes en el ordenamiento juridico. Pero cuando un Estado es Parte de un tratado internacional como la Convención Americana, todos sus órganos, incluidos sus jueces y demás órganos vinculados a la administración de justicia, también están sometidos a aquél, lo cual les obliga a velar para que los

${ }^{33}$ Cfr. Caso Gangaram Panday Vs. Surinam. Excepciones Preliminares. Sentencia de 4 de diciembre de 1991. Serie C No. 12, párr. 50 y Caso Chocrón Chocrón, supra nota 26, párr. 140.

${ }^{34}$ Cfr. Caso Gangaram Panday, supra nota 281, párr. 50 y Caso Chocrón Chocrón, supra nota 26, párr. 140. 
efectos de las disposiciones de la Convención no se vean mermados por la aplicación de normas contrarias a su objeto y fin.

282. - Los jueces y órganos vinculados a la administración de justicia en todos los niveles están en la obligación de ejercer ex officio un «control de convencionalidad» entre las normas internas y la Convención Americana, en el marco de sus respectivas competencias y de las regulaciones procesales correspondientes. En esta tarea, los jueces y órganos vinculados a la administración de justicia deben tener en cuenta no solamente el tratado, sino también la interpretación que del mismo ha hecho la Corte Interamericana, intérprete última de la Convención Americana.

283. - Así, por ejemplo, tribunales de la más alta jerarquía en la región, tales como la Sala Constitucional de la Corte Suprema de Justicia de Costa Rica, el Tribunal Constitucional de Bolivia, la Suprema Corte de Justicia de República Dominicana, el Tribunal Constitucional del Perú, la Corte Suprema de Justicia de la Nación de Argentina, la Corte Constitucional de Colombia, la Suprema Corte de la Nación de México y la Corte Suprema de Panamá se han referido y han aplicado el control de convencionalidad teniendo en cuenta interpretaciones efectuadas por la Corte Interamericana.

284.- En conclusión, con base en el control de convencionalidad, es necesario que las interpretaciones judiciales $y$ administrativas y las garantias judiciales se apliquen adecuándose a los principios establecidos en la jurisprudencia de este Tribunal en el presente caso ${ }^{35}$. Ello es de particular relevancia en relación con lo señalado en el presente caso respecto a la proscripción de la discriminación por la orientación sexual de la persona de acuerdo a lo estipulado en el artículo 1.1. de la Convención Americana (supra apartado C.2).»

Finalmente, en lo que respecta a las indemnizaciones, la $\mathrm{CIDH}$ hace un examen de los diversos factores que han de componer dicha indemnización, señalando al efecto:

«291.- El criterio de equidad ha sido utilizado en la jurisprudencia de esta Corte para la cuantificación de daños inmateriales, de los daños materiales y para fijar el lucro cesante. Sin embargo, al usar este criterio ello no significa que la Corte pueda actuar discrecionalmente al fijar los montos indemnizatorios. Corresponde a las partes precisar claramente la prueba del daño sufrido así como la relación específica de la pretensión pecuniaria con los hechos del caso y las violaciones que se alegan. En el presente caso, los representantes se limitaron a anexar una copia del pago del último dividendo de la señora Atala por la

${ }^{35}$ Cfr. Caso López Mendoza Vs. Venezuela. Fondo Reparaciones y Costas. Sentencia de 1 de septiembre de 2011. Serie C No. 233, párr. 228.

(C) UNED. Revista de Derecho Politico 
mencionada casa y un listado de los valores diarios de la Unidad de Fomento del Banco Central. El Tribunal considera que ello no constituye una argumentación suficientemente detallada y clara para determinar la relación entre las mencionadas unidades de fomento, el pago del dividendo hipotecario, el cuadro demostrativo de las ganancias dejadas de percibir y la cantidad de lucro cesante que, por este concepto, se solicita sea fijada en equidad por la Corte.

292. - Además, dado que debe existir un nexo causal entre los hechos analizados por el Tribunal, las violaciones declaradas anteriormente y el presunto lucro cesante (supra párrs. 287 y 291), la Corte reitera que no le corresponde realizar una ponderación de la prueba obrante en el expediente de tuición del presente caso referente a cuál de los padres de las tres niñas of recía un mejor hogar para las mismas. Por lo tanto, no es procedente que el Tribunal se pronuncie sobre la afirmación de los representantes en el sentido que la pérdida de ganancias respecto a la casa de Villarrica no se habría producido sin la sentencia de la Corte Suprema de Justicia.

293.- Similar conclusión se extiende al análisis de los gastos de transporte de la señora Atala destinados a la visita de sus hijas. En efecto, si la Corte no ha entrado a determinar a cuál de los padres le correspondía la tuición, tampoco puede valorar el impacto económico del régimen de visitas fijado en las decisiones judiciales internas sobre la tuición.

294.- Finalmente, en relación a los gastos relacionados con el tratamiento médico y la compra de medicamentos, la Corte observa que obra prueba en el expediente respecto a dichos gastos y su relación con los efectos que tuvo en la señora Atala la pérdida de la tuición de sus niñas. El Tribunal considera que dicha prueba es razonable para concluir que las violaciones declaradas en la presente Sentencia pudieron tener efectos negativos respecto al bienestar emocional y psicológico de la señora Atala. Sin embargo, el monto solicitado por los gastos en medicamentos realizados hasta 2010 (US\$14.378) no se desprende de manera clara de los certificados anexados. De otra parte, la Corte observa que la señora Atala recibía atención médica por la afectación de su salud desde antes del proceso de tuición. Por lo tanto, la Corte no puede determinar con precisión qué componentes del tratamiento médico se relacionaron exclusivamente con las afectaciones sufridas por las violaciones declaradas en el presente caso. Respecto al pago de los gastos futuros del tratamiento médico por el periodo 2012 2017, la Corte considera que dicho gasto será cubierto por medio de la implementación de la medida de rebabilitación de asistencia médica y psicológica ya ordenada (supra párr. 254 y 255). Por lo tanto, la Corte fija, con base en un criterio de equidad, la suma de US\$10.000 por concepto de los gastos ya realizados por atención médica y psicológica.»

Se fijan asimismo criterios para el establecimiento de indemnizaciones de daños inmateriales, de la siguiente forma:

«299. - Al respecto, la Corte observa que las violaciones declaradas generaron en las víctimas diversos daños en su cotidianidad, diversos niveles de estigmatización y desasosie- 
go. En atención a las indemnizaciones ordenadas por el Tribunal en otros casos, y en consideración de las circunstancias del presente caso, los sufrimientos ocasionados a las víctimas, así como el cambio en las condiciones de vida y las restantes consecuencias de orden inmaterial que sufrieron, la Corte estima pertinente fijar, en equidad, la cantidad de US\$ 20.000 (veinte mil dólares de los Estados Unidos de América) para la señora Atala y de US\$10.000 (diez mil dólares de los Estados Unidos de América) para cada una de las niñas M., V. y R. por concepto de indemnización por daño inmaterial.»

\section{PUNTOS RESOLUTIVOS}

De este modo, la CIDH, resuelve finalmente de la siguiente forma la cuestión sometida a su conocimiento:

«por unanimidad, que:

1.- El Estado es responsable por la violación del derecho a la igualdad y la no discriminación consagrado en el artículo 24, en relación con el artículo 1.1 de la Convención Americana sobre Derechos Humanos, en perjuicio de Karen Atala Riffo, de conformidad con lo establecido en los párrafos 94 a 99, 107 a 146 y 218 a 222 de esta Sentencia.

por unanimidad, que:

2.- El Estado es responsable por la violación del derecho a la igualdad y la no discriminación consagrado en el artículo 24, en relación con los artículos 19 y 1.1. de la Convención Americana, en perjuicio de las niñas M., V. y R., de conformidad con lo establecido en los párrafos 150 a 155 de esta Sentencia.

por unanimidad, que:

3.- El Estado es responsable por la violación del derecho a la vida privada consagrado en el artículo 11.2, en relación con el artículo 1.1. de la Convención Americana, en perjuicio de Karen Atala Riffo, de conformidad con lo establecido en los párrafos 161 a 167 y 225 a 230 de esta Sentencia.

El juez Diego García-Sayán y las juezas Margarette May Macaulay y Rhadys Abreu Blondet votaron a favor del siguiente punto resolutivo. Los jueces Manuel E. Ventura Robles, Leonardo A. Franco y Alberto Pérez Pérez votaron en contra. En consecuencia, en aplicación de los artículos 23.3 del Estatuto de la Corte Interamericana de Derechos Humanos y 16.4 del Reglamento de la Corte Interamericana de Derechos Humanos, se declara que:

(C) UNED. Revista de Derecho Politico

N. ${ }^{\circ}$ 85, septiembre-diciembre 2012, pág. 349-394 
4.- El Estado es responsable de la violación de los artículos 11.2 y 17.1, en relación con el artículo 1.1 de la Convención Americana en perjuicio de Karen Atala Riffo y de las niñas M., V. y R., de conformidad con lo establecido en los párrafos 168 a 178 de esta Sentencia.

por unanimidad, que:

5. - El Estado es responsable por la violación del derecho a ser oído consagrado en el artículo 8.1, en relación con los artículos 19 y 1.1 de la Convención Americana en perjuicio de las niñas M., V. y R., de conformidad con lo establecido en los párrafos 196 a 208 de esta Sentencia.

por unanimidad, que:

6. - El Estado es responsable por la violación de la garantía de imparcialidad consagrada en el artículo 8.1, en relación con el artículo 1.1 de la Convención Americana, respecto a la investigación disciplinaria, en perjuicio de Karen Atala Riffo, de conformidad con lo establecido en los párrafos 234 a 237 de esta Sentencia.

por cinco votos a favor y uno en contra, que:

7.- El Estado no violó la garantía judicial de imparcialidad consagrada en el artículo 8.1 de la Convención Americana, en relación con las decisiones de la Corte Suprema de Justicia y el Juzgado de Menores de Villarrica, en los términos de los párrafos 187 a 192 de la presente Sentencia.»

\section{CONCLUSIONES}

9.1. Corte Interamericana de Derecho Humanos (Considerandos 64-66) ${ }^{36}$

a.- La CIDH reitera que la jurisdicción internacional «de carácter subsidiario», no es una «cuarta instancia», por lo que corresponde a los tribunales del Estado examinar hechos y prueba.

b.- La CIDH, no es competente para resolver acerca de la custodia de las niñas M. V. y R., lo que es materia de derecho interno y de la jurisdicción doméstica.

${ }^{36}$ Los «considerandos», equivalen a los «fundamentos jurídicos», de la sentencia de la Corte Interamericana de Derechos Humanos, y a sus respectivos numerales. 
C.- Esta prevención judicial inicial es clave para entender la deferencia de la $\mathrm{CIDH}$, en relación al derecho interno (derecho de familia), sin ejercer el polémico «control de convencionalidad» en relación al legislador del Estado (v.gr. artículo 225 del Código Civil), y al mismo tiempo, hacer un examen de la tutela judicial expedida por la Corte Suprema en sede de queja y que es lesiva de derechos humanos y garantías del sistema interamericano en especial.

d.- La CIDH es por regla una judicatura activista en exceso, pero en este caso expide una sentencia benigna al Estado, no ejerciendo el «control de convencionalidad en relación al Gobierno y al Congreso Nacional, y tratando en las reparaciones o medidas con complacencia al Estado; aunque no así a los tribunales nacionales, en especial a la Corte Suprema, a los que sí somete a control de convencionalidad, exhortando a seguir la doctrina jurisprudencial del sistema interamericano. El proceso interamericano aquí se expresa en puridad como jurisdicción internacional subsidiaria, y no jurisdicción transnacional, sometiéndose a enjuiciamiento la tutela judicial en el Estado nacional parte del sistema y su adecuación a la tabla de derechos, que es el derecho material de la Corte de Costa Rica.

\subsection{Igualdad y No Discriminación}

La sentencia de la CIDH recoge una definición de los alcances de la prohibición de discriminación en el ámbito del género, y las preferencias u orientaciones sexuales de las personas (cons. 72 a 74).

Asimismo, la discriminación es ligada al derecho de igualdad (cons. 78 a 80), con especial énfasis en otros instrumentos internacionales que enuncian estándares sospechosos y definen discriminación o tratos discriminatorios (cons. 81).

De este modo, la orientación sexual queda comprendida en el Art. 1.1 de la Convención Americana de Derechos Humanos, que prohíbe discriminar por «cualquier otra condición social», para lo cual se busca con exceso por los sentenciadores el argumento de autoridad del Tribunal Europeo de Derechos Humanos — TEDH- (cons. 83, 87) y del sistema de protección de la ONU (cons. $88,89$ y 90$)$.

Nuclearmente, la CIDH, concluye:

«94.- El Tribunal resalta que para comprobar que una diferenciación de trato ha sido utilizada en una decisión particular, no es necesario que la totalidad de dicha decisión esté basada «fundamental y únicamente» en la orientación sexual de la persona, pues basta con constatar que de manera explícita o implícita se tuvo en cuenta hasta cierto grado la orientación sexual de la persona para adoptar una determinada decisión.»

Luego, para la CIDH, el «interés superior del niño», no es un comodín o excusa para decidir acerca de la custodia y tuición de los niños, comodín empleado 
por la Corte Suprema (cons. 107 y siguientes) y que le sirve a su argumentación (cons. 113). La CIDH apunta a un problema toral, un ámbito del derecho de familia que se plasma normativamente en una cierta «moral pública», y es que tal moralidad desencadenante de discriminación social de las menores, no puede ser la excusa de un Tribunal para perpetuar «tratos discriminatorios», ya que el Estado, en materia de Derechos Humanos, tiene roles negativos, de respeto o protección y positivos de promoción de derechos y sus garantías. En suma, el derecho, los Estados, los jueces, deben coadyuvar al «avance social», señala la CIDH (cons. 116).

La CIDH, indica que el Estado, tratándose de la prohibición de discriminación por orientación sexual y de la restricción de derechos, debe asumir el traslado a éste de la carga de la prueba y exige un test estricto (causalidad entre la orientación sexual de la madre y el daño en las niñas, daños específicos y concretos), que la Corte Suprema no cumple.

\subsection{Derecho a la Vida Privada}

Para la CIDH la libertad sexual, expresada en una orientación sexual de las personas, no sólo comprende la garantía de prohibición de «tratos discriminatorios», sino también el derecho a expresar toda preferencia, como expresión libre de la personalidad (autodeterminación) de la vida privada y pública (cons. 135-136).

Para ello, la CIDH, construye un concepto de familia y vida familiar sociológico-cultural, no ético-religioso o naturalístico, concepto contemporáneo, laico, secular, fundado en los derechos de libertad de las personas, por lo que la Convención Americana de Derechos Humanos no protegió un modelo «tradicional de familia» (cons. 142); aspecto en que se observa una disidencia en la sentencia del juez Alberto Pérez Pérez. Para este contemporáneo concepto de familia, la CIDH recurre nuevamente al argumento de autoridad del Tribunal Europeo de Derechos Humanos (cons. 144), a la doctrina del Tribunal de Estrasburgo en el caso «Salgueiro da Silva Mouta vs. Portugal» de 1999.

En consecuencia, para la CIDH, la Corte Suprema y los tribunales de instancia, utilizan «argumentos abstractos, estereotipados y discriminatorios» para fundar sus decisiones por lo que el trato discriminatorio vulnera el derecho de igualdad del Art. 24 en relación al Art. 1.1 de la Convención Americana de Derechos Humanos (cons. 146). Este trato discriminatorio se proyecta a las niñas M. V. y R (cons. 151-152). A ello se agrega la lesión al derecho a la vida privada al utilizar la orientación sexual lésbica como elemento central para determinar la idoneidad de madre con tuición de sus hijas (cons. 167).

\subsection{Obiter Dicta: Recurso de Queja y Tutela Judicial}


La CIDH hace un documentado examen del recurso de queja en nuestra legislación de enjuiciamiento y su aptitud para revocar sentencias dictadas con falta o abuso, sede de queja en que el tribunal enjuicia hechos, prueba y derecho, una verdadera «instancia» procesal del todo anómala. Por lo que el recurso de queja empleado por la Corte Suprema problematiza los principios del Estado de Derecho: el principio de separación de poderes e independencia judicial ad intra (cons. 185 a 189), descartando que se produzca una infracción al principio de imparcialidad.

Consigna la sentencia, asociada a las garantías judiciales del Art. 8 de la Convención Americana de Derechos Humanos, un interesante obiter dicta, sobre el «derecho de las niñas a ser escuchadas», por un tribunal, en atención a su desarrollo, y fundado en el obiter dicta, interpreta que se infringe la garantía del derecho a ser oído o escuchado por el tribunal (Art. 8.1).

\subsection{Derechos y Garantías en Procedimiento Disciplinario}

$\mathrm{La} \mathrm{CIDH}$, evaluando el procedimiento disciplinario llevado contra la Sra. Atala Riffo, concluye que se interfiere con la garantía de prohibición de discriminación, fundado en la centralidad de la condición sexual de la pasible en dicho proceso (Art. 24 en relación al Art. 1.1 de la Convención Americana de Derechos Humanos). En el mismo proceso disciplinario, estima la CIDH se lesionó el derecho a la vida privada (Art. 11.2 y Art. 1.1 de la Convención).

\subsection{Reparación}

Las reparaciones que la CIDH emplea, se basan en la idea clásica de la «restitutio in integrum», causales a los hechos, vulneraciones de derechos y daños acreditados respecto de la Sra. Atala Riffo y de las niñas M. V. y R. (cons. 245). Se ordena la concurrencia de una panoplia de reparaciones y medidas correctivas (con. 267); que a nuestro juicio dan cuenta de un trato benigno al Estado.

\subsection{Control de convencionalidad limitado}

Como decíamos al comenzar este apartado sumario de conclusiones, la $\mathrm{CIDH}$, con especial deferencia al derecho nacional y al margen de la solución nacional que brinde el legislador y los gobiernos en materia de derecho de familia, descarta el ejercicio del polémico «control de convencionalidad» en relación a este punto. Ello está en contraste con el acusado activismo de la CIDH y del empleo desmesurado del mentado «control de convencionalidad», que en otros lugares hemos sometido a crítica. Pero, con todo, la CIDH despliega una di- 
mensión de «control de convencionalidad» que es la relativa a los tribunales nacionales y al seguimiento de su doctrina jurisprudencial, amén del cumplimiento de sus sentencias; con la finalidad de conectar la tutela judicial estatal de derechos y garantías con la tutela que brinda el sistema interamericano de protección de derechos (cons. 270, 280).

Sin perjuicio de lo expuesto, la $\mathrm{CIDH}$, no renuncia a que los tribunales nacionales hagan seguimiento de la doctrina jurisprudencial interamericana (cons. 284); materia en la que observamos un déficit en nuestros tribunales nacionales.

Prospectivamente, la sentencia de la CIDH comunicada el día 21 de marzo de 2012, y recibida con «beneplácito» por el Gobierno, Congreso Nacional, y organizaciones de la sociedad civil y «distancia» respetuosa de la Corte Suprema; está llamada a incidir poderosamente en nuestra cultura de los derechos humanos y perspectiva garantista. La sentencia de la CIDH comentada asume un patrón hermenéutico progresivo-evolutivo de los derechos humanos y sus garantías, desde un ethos contemporáneo o moderno, laico, secular que se refleja en un concepto de vida familiar, libertad sexual, autodeterminación y libre desarrollo de la personalidad en conexión con la orientación sexual y determinación de género de las personas. Este ethos es reflejo del poderoso influjo que el Tribunal de Estrasburgo ejerce en la Corte de Costa Rica; influjo que conecta con los sistemas de protección de derechos vigentes. Luego, la doctrina jurisprudencial de la CIDH no sólo es prometedora para minorías sexuales, o minorías culturales, sino en general es un paso en la consolidación de una cultura garantista.

Por otra parte, la necesidad de una doctrina del seguimiento de la jurisprudencia y doctrina de la CIDH y del sistema interamericano se vuelve imperiosa para nuestros tribunales en general y la Corte Suprema en particular, seguimiento que no importe admitir el «control de convencionalidad», sino un juicio crítico y positivo del obrar jurisprudente en el sistema. Este seguimiento es plenamente coherente con las obligaciones impuestas por la Convención Americana de Derechos Humanos, cuyas normas deben ser cumplidas y de buena fe por los estados.

Tal doctrina del seguimiento también puede resultar capital para el Tribunal Constitucional, que sin necesidad de exorbitar el derecho constitucional material a través de un «bloque constitucional de derechos», puede incorporarlo a las coordenadas de una cultura jurídica garantista. De la mano de esta cultura jurídica garantista, la sentencia comentada refleja un ethos contemporáneo o moderno, laico y secular, y a patrones hermenéuticos progresivos-evolutivos, lejana de patrones hermenéuticos conservadores-originalistas y de lecturas, comprensionesprecomprensiones de los derechos humanos y de las garantías prisioneras de escoramientos ideológicos neoiusnaturalistas.

Por último, la sentencia de la CIDH recaída en el caso «Atala Riffo y niñas vs. Chile» abre un interesante debate en la comunidad científica y forense, no exenta de corsés ideológicos, no sólo acerca del acusado activismo de la Judicatura 
interamericana, del mentado «control de convencionalidad», de la descuidada protección de derechos sociales, sino de los márgenes o límites de la Judicatura y proceso interamericano, y ciertamente de su precaria legitimidad democrática. Pero, debemos tener cuidado con disfrazar un rechazo ideológico a la doctrina jurisprudencial de la $\mathrm{CIDH}$ y la cultura garantista en materia de derechos, con una línea argumental «nacionalista»-parroquial, neoiusnaturalista, neoliberal, que apela a una moral pública nacional, y a los deficitarios estándares de generación y control democráticos, de rendición de cuentas, y de equilibrio en la legitimidad procesal, o simplemente al origen e ideologías profesadas por los jueces interamericanos, como si tales déficit sólo fueren predicables de este sistema judicial. Es decir, se requiere de un debate académico y forense serio y franco acerca del sistema interamericano de protección de derechos y su Corte. El principio del debate puede ser el «control de convencionalidad»; la doctrina y definición de política judicial activista más dura de la Judicatura interamericana. En cambio, situar el debate en los aportes del sistema interamericano a la cultura jurídica garantista desde una ethos moderno, contemporáneo, laico y secular, es poner en tela de juicio la internacionalización de los derechos humanos, como etapa en la evolución de los derechos humanos que viene a cumplir casi cien años ${ }^{37}$.

Title:

COMMENTARY ON THE JUDGMENT OF INTER-AMERICAN COURT OF HUMAN RIGHTS, CASE OF «ATALA RIFFO AND GIRLS VS. CHILE», FEBRUARY 24, 2012

\section{Resumen:}

El trabajo es un comentario a la sentencia dictada por la Corte Interamericana de Derechos Humanos, que decide acerca de la vulneración a los derechos humanos, producida por la sentencia de la Corte Suprema de Chile, que priva a Karen Atalla Riffo de la tuición de sus hijas por convivir, en una relación homosexual, con otra mujer.

\section{Abstract:}

${ }^{37}$ COVARRUBIAS, Ignacio. ALVEAR, Julio. VERDUGO, Sergio. «La Corte Interamericana: Legitimidad en Entredicho», en El Mercurio, de fecha 24 de Marzo de 2012. 
The work is a commentary on the judgment of the Inter-American Court of Human Rights, which decides about the violation of human rights, produced by the judgment of the Supreme Court of Chile, which deprives Karen Atala Riffo of custody their daughters to live in a homosexual relationship with another woman.

Palabras clave:

Derechos Humanos, Igualdad, Privacidad, Orientación Sexual.

Key words:

Human Rights, Equality, Privacy, Sexual Orientation. 